\title{
Relationships Among Authentic Leadership, Manager Incivility and Trust in the Manager
}

Ohood Ali Alkaabi, The University of Western Ontario

Supervisor: Dr. Carol Wong, The University of Western Ontario

A thesis submitted in partial fulfillment of the requirements for the Master of Science degree in Nursing

(C) Ohood Ali Alkaabi 2018

Follow this and additional works at: https://ir.lib.uwo.ca/etd

Part of the Community College Education Administration Commons, and the Nursing Administration Commons

\section{Recommended Citation}

Alkaabi, Ohood Ali, "Relationships Among Authentic Leadership, Manager Incivility and Trust in the Manager" (2018). Electronic Thesis and Dissertation Repository. 5634.

https://ir.lib.uwo.ca/etd/5634

This Dissertation/Thesis is brought to you for free and open access by Scholarship@Western. It has been accepted for inclusion in Electronic Thesis and Dissertation Repository by an authorized administrator of Scholarship@Western. For more information, please contact wlswadmin@uwo.ca. 


\begin{abstract}
There have been growing concerns about manager incivility toward new graduate nurses which hinders their adaptation to the workplace environment. Manager incivility impairs the relationship between managers and their staff. Furthermore, nursing managers have a significant responsibility to facilitate new graduate nurses' transition into the nursing profession. The purpose of this secondary analysis was to examine the relationships among authentic leadership of managers and new graduate nurses' experience of manager incivility and their subsequent degree of trust in their managers. Secondary analysis of the baseline data using a non-experimental, correlational design was conducted. A random sample of 1020 new graduate nurses from all 10 Canadian provinces was obtained. The hypothesized model was tested using hierarchical multiple linear regression. Authentic leadership had a negative relationship with manager incivility which in turn was negatively related to trust in the manager and overall, the model accounted for $59.9 \%$ of the variance in trust. In addition, authentic leadership was positively associated with trust in the manager. The findings supported that authentic leadership may be an effective approach to enhance manager-nurse interactions and authentic managers are less likely to display uncivil behaviour which diminishes trust. Findings may be useful to inform the development of positive and respectful work environments as well as the everyday practice of nurse managers.
\end{abstract}

Keywords: Authentic leadership, manager incivility, uncivil behaviour, trust in the manager, healthy work environment. 


\section{DEDICATION}

I dedicate this thesis to my grandmother who taught me to be assertive on my goals, and my non-biological sister Fawziah Almalki who unconditionally supports and loves me all the time. 


\section{ACKNOWLEDGEMENTS}

My sincere thanks goes to all administrative members and the faculty at the Arthur Labatt Family School of Nursing for their great cooperation and excellent facilitation of my learning experience. In particular, the greatest gratitude goes to my supervisor (Dr. Carol A. Wong) for her valuable guidance and wonderful collaboration. She has supported and helped me greatly throughout the thesis journey. She has demonstrated the authentic leadership approach through being approachable, supportive and open for free communication during regular meetings.

I also would like to thank the pain that I went through in my life. Don't be surprised, but a painful moment when I almost thought this is the end, has made me patient, strong, a fighter, ambitious, and optimistic. The pain is the spark that pushes me to chase high and achieve success. I am really thankful for my belief of "what does not kill you makes you stronger". And, I would like to thank my grandmamma who devoted her time and effort to raise me and strived to let me continue my education. I would like to acknowledge that although I have been struggling throughout my life, I have a precious non-biological sister Fawziah Almalki who has been taking care of me and standing by my side in my happiness and sadness. She is my lifemate. 


\section{TABLE OF CONTENTS}

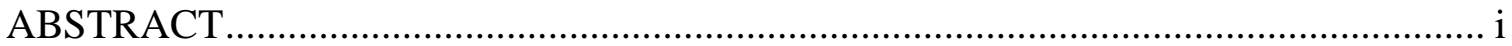

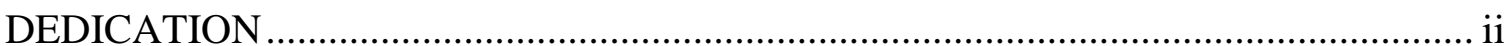

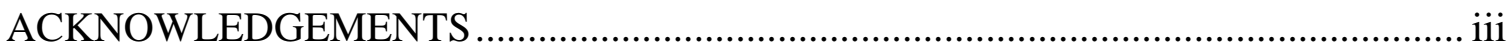

TABLE OF CONTENTS .......................................................................................... iv

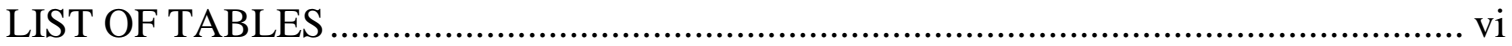

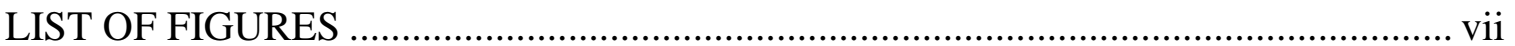

LIST OF APPENDICES ..................................................................................... vii

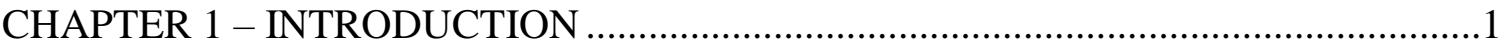

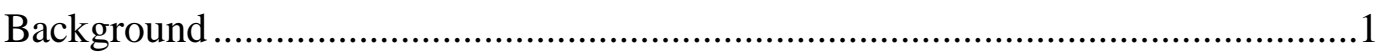

Healthy Work Environments and New Graduate Nurses ............................1

Authentic Leadership ................................................................................

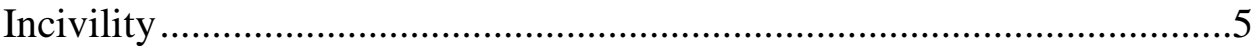

Trust in the Managers ............................................................................

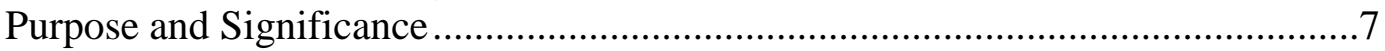

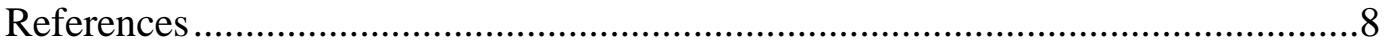

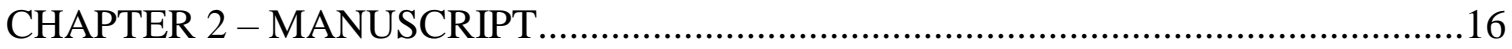

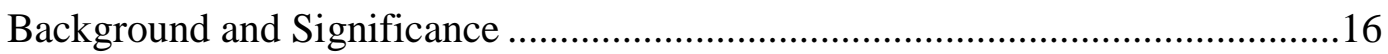

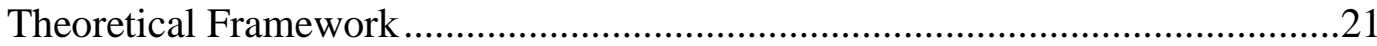

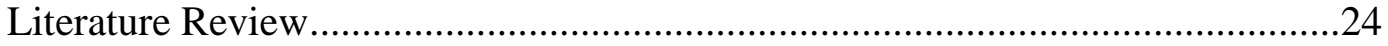

Authentic Leadership .......................................................................24

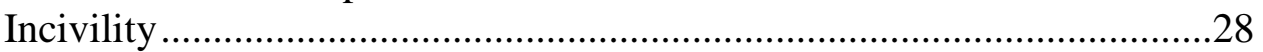

Trust in Manager...................................................................................

Summary of the Literature .....................................................................34

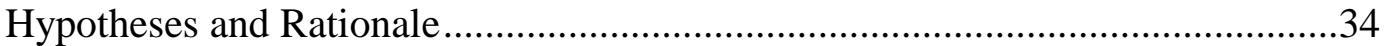

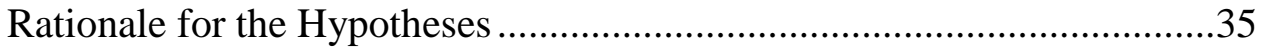

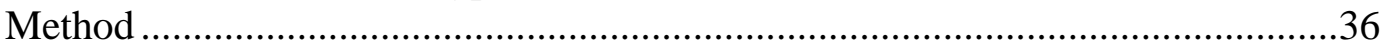

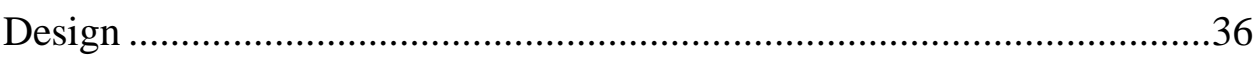

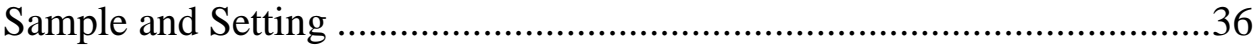

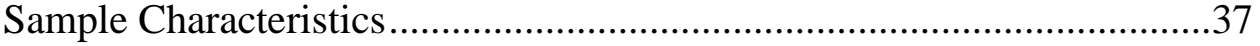

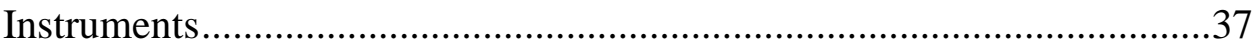

Authentic Leadership ...............................................................39

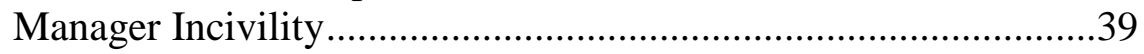

Trust in Manager........................................................................39

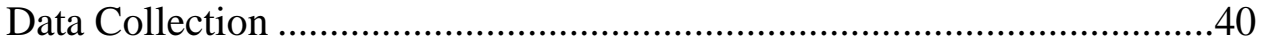

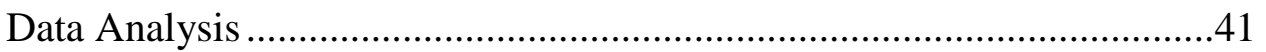

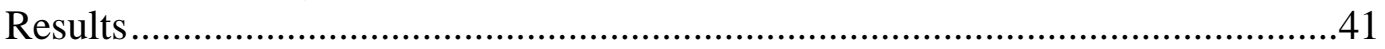

Descriptive Results ..................................................................................

Relationship of Demographic Variables to Major Study Variables ...........42

Correlation Analysis ............................................................................42

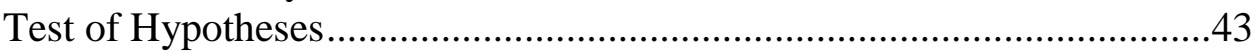


Table of Contents (Continued)

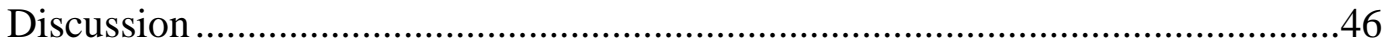

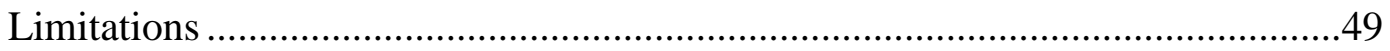

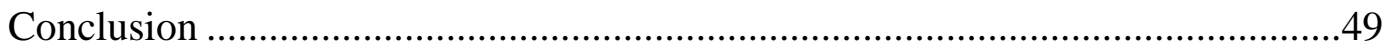

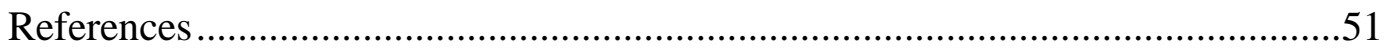

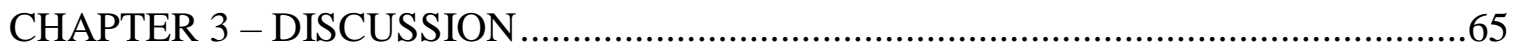

Implications for Theory ….......................................................................6

Implications for Healthcare Organizations ....................................................66

Implications for Healthcare Management Practice ..............................................67

Implications for Future Research ...............................................................69

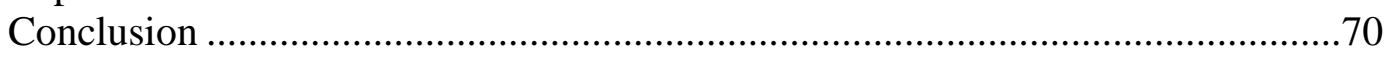

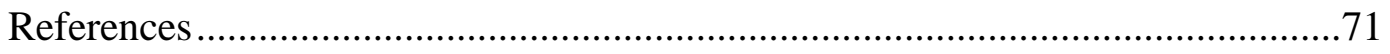

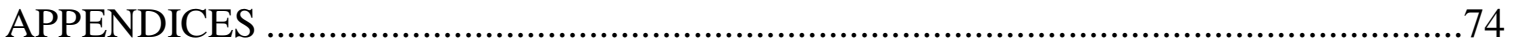

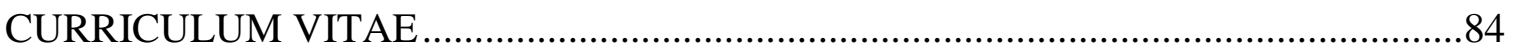




\section{LIST OF TABLES}

Table

Description

Page

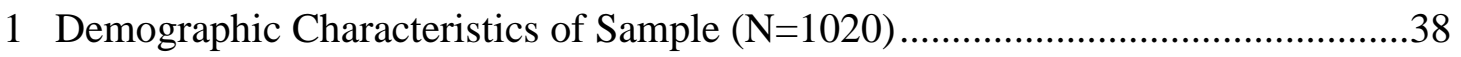

2 Means (M), Standard Deviations (SD), Reliabilities ( $\alpha$ ) and Correlation Matrix ...44

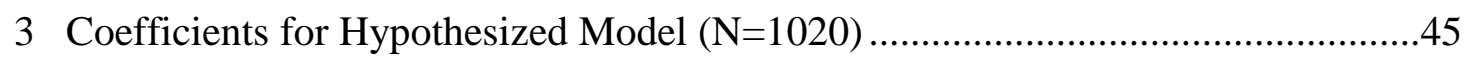




\section{LIST OF FIGURES}

Figure

Description

Page

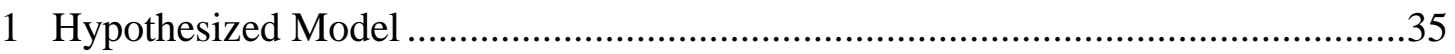

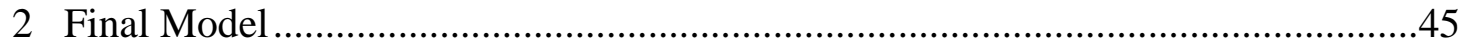




\section{LIST OF APPENDICES}

Appendix A Ethical Approval Form for Original Study ............................................74

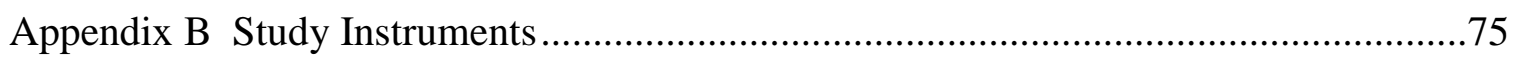

B. 01 Authentic Leadership Questionnaire.....................................................

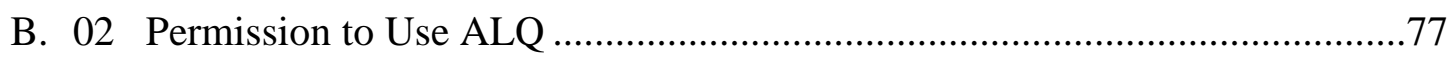

B. 03 Straightforward Incivility Scale - Supervisor Incivility .............................78

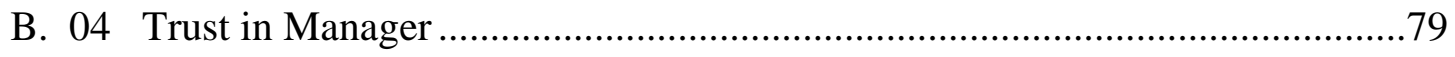

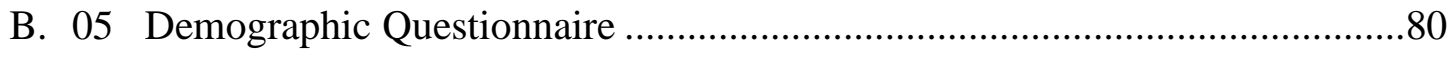

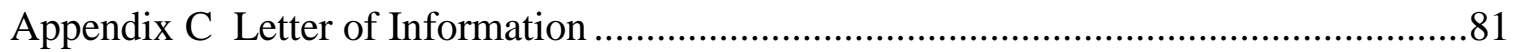




\section{CHAPTER 1}

\section{INTRODUCTION}

Workplace environments are considered to be important factors that contribute to recruitment and retention challenges in nursing (Oulton, 2006; Kingma, 2001). It is predicted that the demand for nurses in practice is increasing; however, supporting resources may decrease as economic constraints in healthcare continue (Buchan \& Aiken, 2008). Globally, nursing positions are predicted to fall anywhere from 28500 to 1,000.000 in one decade (Ritter, 2011). In Canada, the Canadian Institute for Health Information (2017) reported the province of Ontario had the lowest (of 10 provinces) RN-to-population ratio where 703 RNs per 100,000 people, decreased from 711 RNs in 2015. This nursing shortage may be critical because nurses are the largest group of health professionals operating in health organizations (McMullin \& Cooke 2004). Therefore, it is crucial that the nursing workplace is effectively structured to promote work engagement, positive performance (Laschinger, Leiter, Day, \& Gilin, 2009) and efficient workflow. Moreover, nurse managers support healthy work environments by building relationships and trust with nurses, creating empowering work environments, and balancing competing values and priorities (Registered Nurses Association of Ontario, 2013)

\section{Background}

\section{Healthy Work Environments and New Graduate Nurses}

Conditions of an unhealthy work environment may include ineffective communication, abusive and disrespectful behaviour, lack of visionary leadership, absence of trust, repetitive and unresolved conflict and waning commitment to core values of the organization (Heath, Johanson \& Blake, 2004). Conversely, a healthy 
workplace incorporates clear policies, procedures and processes to achieve organizational goals, empower nurses, improve job satisfaction and prevent nurses from leaving their jobs (Shirey, 2006). “An organization is not its products, markets, or technologies rather it is in the repetitious patterns of how people relate to each other, gather and interpret information, solve problems, make decisions, manage conflict, and implement change while accomplishing the organization's purpose" (Bushe, 2010. p. 40).

A healthy workplace environment (HWE) is essential to improve nurses' performance and organizational outcomes whereas a poor workplace environment results in a negative impact on psychological capital, quality of healthcare, and patient safety (Wei, Sewell, Woody, \& Rose, 2018). Unhealthy workplace cultures result in increased turnover rates, absenteeism, high stress levels, and lack of collaboration among health professionals (Heath et al. 2004). Job turnover intention rates are increasing among millennial generation nurses due to high levels of psychological distress, high job demands, and insufficient support (Lavoie-Tremblay et al., 2010). As well, LavoieTremblay, Paquet, and Marchionni (2011) found that new graduate nurses (NGNs) were more likely to quit their jobs when they had poor participation in hospital affairs and ineffective communication with physicians which lead to low quality of care. Poor communication between nurses and physicians puts patient safety at risk. Manojlovich and De Cicco (2007) suggested that the medication error rate decreased when nurses and physicians communicated effectively.

New graduate nurses have encountered many difficulties adapting to their work environment. Two Canadian studies of practice readiness found that there was a significant and problematic developmental gap when shifting from being students to licensed nurses in the workplace (Romyn et al., 2009; Wolff, Pesut, Regan \& Regan, 
2010). New graduate nurses often felt unprepared for practice demands such as long shifts, complex patient health problems, and important communication with colleagues and physicians (Heslop, McIntyre, \& Ives, 2001). Even though there are established programs to support NGNs, $33 \%$ to $50 \%$ have reported being bullied by other healthcare providers (Laschinger, Grau, Finegan, \& Wilk, 2010). This happens more frequently with NGNs compared to experienced nurses because of their junior position within the organizational hierarchy and lack of experience (Rush, Adamack, Gordon, \& Janke, 2014).

Nursing mangers are challenged to facilitate successful transition of NGNs to the practice setting. Regan et al., (2016) illustrated that nursing managers make a substantial contribution to supporting professional nursing environments and encouraging NGNs to participate in interprofessional collaborative practice. New graduate nurses need to feel supported to effectively engage in their new positions and become effective interprofessional team members (Laschinger \& Smith, 2013). Nursing managers can facilitate NGNs' work by providing high quality support and empowering them with available resources (Laschinger, Wong \& Grau, 2013). There have been various supportive programs such as preceptorship established for NGNs as newcomers to healthcare organizations. Preceptorship helps NGNs to acquire positive professional attitudes and behaviour that are essential to build professional relationships (Hayes \& Sexton Scott, 2007). Furthermore, Casey, Fink, Krugman, and Propst (2004) found that NGNs who received longer orientation were more satisfied with their jobs. Nursing managers play a vital role in facilitating preceptorship by providing adequate supervision, support, and consistent constructive feedback to NGNs (Russell, Hobson \& Watts, 2011). For instance, nurse managers provide support by scheduling positive nursing staff to 
mentor NGNs, fostering participation in education programs and providing a supportive environment that facilitates NGNs to practice according to what they have learned in their education programs (RN.com, 2018). Therefore, ongoing support from nurse managers is an important factor to reduce adverse impacts of being NGNs.

\section{Authentic Leadership}

Authentic leadership is an emerging relational leadership style that "encourages openness in sharing information needed to make decisions while accepting followers' inputs" (Avolio, Walumbwa \& Weber, 2009, p. 424). Authentic leaders are described as leaders who display high levels of authenticity (Avolio, Gardner, Walumbwa, Luthans \& May, 2004). Indeed, authenticity is defined as being very aware of one's thoughts, emotions, beliefs, needs and desires (Harter,2002). Erickson (1994) and Heidegger, (1962) agreed that leaders who show more genuine values, thoughts, preferences, emotions and beliefs become more authentic. Hence, authentic leaders know who they are, their values and beliefs, and they act in accord with their true self (Avolio et al., 2004), Also, authentic leaders are confident, hopeful, optimistic, resilient, and high on moral character, and they are able to increase work engagement, motivation, commitment and satisfaction of the followers which contributes to improving their performance outcomes (Avolio et al. 2004).

Authentic managers play a crucial role in creating a supportive workplace culture for NGNs. Authentic managers can decrease workplace stress that involves role ambiguity, overload, and unrealistic expectations by being open and transparent in their interactions with nurses and considerate of others' opinions in making decisions (Laschinger, Wong \& Grau, 2012). Empirically, supportive leaders have been found to be a significant predictor of lower emotional exhaustion among NGNs (Spooner-Lane \& 
Patton, 2007). Moreover, Hauge et al. (2011) found that employees who were led by fair and supportive leaders reported fewer bullying experiences in their workplace. Also, Read and Laschinger (2013) found that authentic leaders are less likely to demonstrate uncivil behaviour. Authentic leaders positively foster work environments though reflection of their core values and goals (Peus, Wesche, Streicher, Braun \& Frey 2012).

\section{Incivility}

Nevertheless, incivility is a devastating form of workplace mistreatment which profoundly affects NGNs (Armstrong, 2018). Zauderer's definition of incivility (2002) is “impolite behavior or bad manners" (p. 37). Additionally, MacKinnon (1993) described incivility as a harbinger to aggression, harassment, and physical assault. Namie (2003) considered incivility as one type of workplace disruption, and Laschinger, Wong, Regan, Young-Ritchie, and Bushell (2013) viewed it as a threat to the workplace environment. Co-workers, physicians, and supervisors can be guilty of workplace incivility (McNamara, 2012). New graduate nurses are vulnerable to incivility because of their novice status which may negatively impact their mental health (Laschinger et al., 2013). Workplace incivility has been linked to depression and anxiety (Hansen et al., 2006). (Laschinger \& Read, 2016), and has a significant effect on attitudinal, cognitive, and behavioural outcomes such as low trust in the immediate manager (Schilpzanda, Pater, \& Erez, 2016). Specifically, the employees experiencing incivility were found to show lower affective trust or lower feelings of care and concern from others (Cameron \& Webster, 2011).

\section{Trust in the Manager}

Trust in the manager is an important value associated with healthy work environments (Lowe, 2006). Trust has been defined as "the willingness of a party to be 
vulnerable to the actions of another party based on the expectation that the other will perform a particular action important to the trustor, irrespective of the ability to monitor or control that other part" (Mayer, Davis, and Schoorman,1995, p. 702). Mayer and colleagues' (1995) theory of trust identified three important trustee's characteristics as ability, benevolence, and integrity. Ability is "the perception that a trustee has skills and competencies in the domain of interest"; benevolence is "perception that the trustee cares about the trustor, and integrity is the perception that the trustee adheres to a set of principles that the trustor finds acceptable" (p.703). These three components of trustworthiness have been correlated with trust in the leader or manager (Davis, Schoorman, Mayer, \& Tan, 2000; Mayer and Davis, 1999). Importantly, trust in managers was significantly and positively related to followers' behaviour and performance (Dirks \& Ferrin, 2002). Mayer and Gavin's (2005) model indicated that trust in managers affects followers' performance through allowing them to stay focused on tasks. Trust in managers was related to follower's ability to stay focused on "valueproducing activities" (p. 883) which was subsequently related to job-performance. Colquitt, Scott and LePine, (2007) found trust in management had a strong relationship with better job performance, more organizational citizenship behaviours, and less intentions to quit. Also, trust in managers positively related to job satisfaction (Tan \& Tan, 2000). Moreover, in nursing, Laschinger and Finegan, (2005) conducted a study aimed to examine the impact of employee empowerment on perceptions of organizational justice, respect, and trust in managers among nursing staff in Ontario. The findings revealed that trust in managers has been significantly related to the feeling of being respected. 


\section{Purpose and Significance}

Authentic leadership is an essential approach to foster healthy workplace environments that are characterized by healthy relationships and mutual trust between managers and their followers. Avolio et al. (2004) developed the theoretical framework of authentic leadership that explains how manager behaviours and attitudes influence followers' performance. However, there is a significant gap in the nursing literature that examines how manager incivility may affect gaining trust from their followers.

Therefore, the purpose of this study was to test the relationships among authentic leadership of managers, NGNs' experience of manager incivility, and their subsequent degree of trust in their managers. The results of this study will add further knowledge to authentic leadership in practice and may help leaders to improve their attitude and behaviours toward NGNs and enhance interpersonal relationships. Also, the results may be important for nursing managers to facilitate the workplace environment for NGNs during their transition to practice. Findings may also provide evidence for effective solutions to manager incivility. For this study, Avolio et al.'s (2004) theory of authentic leadership was used as the theoretical framework to a gain better understanding of the relationship among the study variables. 


\section{References}

Armstrong, N. (2018). Management of nursing workplace incivility in the health care settings: a systematic review. Workplace Health \& Safety, 2165079918771106.

Avolio, B. J., Gardner, W. L., Walumbwa, F. O., Luthans, F., \& May, D. R. (2004). Unlocking the mask: A look at the process by which authentic leaders impact follower attitudes and behaviors. The Leadership Quarterly, 15(6), 801-823. doi:10.1016/j.leaqua.2004.09.003

Avolio, B., Walumbwa, F., \& Weber, T. (2009). Leadership: Current theories, research and future directions. Annual Review of Psychology, 60, 421-449.

Boychuk Duchscher, J.E., \& Cowin, L.S. (2006). The new graduates’ professional inheritance. Nursing Outlook, 54(3), 152-158.

Buchan, J., \& Aiken, L. (2008). Solving nursing shortages: a common priority. Journal of Clinical Nursing, 17(24), 3262-3268.

Bushe, G. R. (2011). Clear leadership: Sustaining real collaboration and partnership at Work. Nicholas Brealey Publishing.

Canadian Institute for Health Information (2017). Regulated nurses, 2016. Retrieved from https://www.cihi.ca/sites/default/files/document/regulated-nurses-2016report-en-web.pdf

Cameron, A. F., \& Webster, J. (2011). Relational outcomes of multicommunicating: Integrating incivility and social exchange perspectives. Organization Science, 22(3), 754-771.

Casey, K., Fink, R., Krugman, M., Propst, J., 2004. The graduate nurse experience. Journal of Nursing Administration, 34 (6), 303-311. 
Chang, E., \& Hancock, K. (2003). Role stress and role ambiguity in new nursing graduates in Australia. Nursing \& Health Sciences, 5(2), 155-163.

Colquitt, J. A., Scott, B. A., \& LePine, J. A. (2007). Trust, trustworthiness, and trust propensity: A meta-analytic test of their unique relationships with risk taking and job performance. Journal of Applied Psychology, 92(4), 909-927.

doi:10.1037/0021-9010.92.4.909

Davis, J. H., Schoorman, F. D., Mayer, R. C., \& Tan, H. H. (2000). The trusted general manager and business unit performance: Empirical evidence of a competitive advantage. Strategic Management Journal, 21(5), 563-576.

Dirks, K. T., \& Ferrin, D. L. (2002). Trust in leadership: meta-analytic findings and implications for research and practice. Journal of Applied Psychology, 87(4), 611.

Erickson, R. J. (1994). Our society, our selves: Becoming authentic in an inauthentic world. Advanced Development, 6, 27 - 39.

Hansen, Å. M., Hogh, A., Persson, R., Karlson, B., Garde, A. H., \& Ørbaek, P. (2006). Bullying at work, health outcomes, and physiological stress response. Journal of Psychosomatic Research, 60(1), 63-72.

Harter, S. (2002). Authenticity. In C. R. Snyder, \& S. Lopez (Eds.), Handbook of positive psychology (pp. 382-394). Oxford, UK7 Oxford University Press.

Hauge, L. J., Einarsen, S., Knardahl, S., Lau, B., Notelaers, G., \& Skogstad, A. (2011). Leadership and role stressors as departmental level predictors of workplace bullying. International Journal of Stress Management, 18(4), 305-323. http://dx.doi.org/10.1037/a0025396

Hayes J.M. \& Sexton Scott A.S. (2007) Mentoring partnership as the wave of the future for new graduates. Nursing Education Perspectives, 28, 27-30. 
Heath J., Johanson W. \& Blake N. (2004) Healthy work environments: a validation of the literature. The Journal of Nursing Administration, 34 (11), 524-530.

Heidegger, M. (1962). Being and time (J. Macquirrie and E. Robinson, Trans.). New York7 Harper and Row.

Heslop, L., McIntyre, M., \& Ives, G. (2001). Undergraduate student nurses’ expectations and their self-reported preparedness for the graduate year role. Journal of Advanced Nursing, 36, 626-634.

Kingma, M. (2001). Nursing migration: Global treasure hunt or disaster-in-the-making? Nursing Inquiry, 8, 205-212.

Laschinger, H. K. S., \& Finegan, J. (2005). Using empowerment to build trust and respect in the workplace: A strategy for addressing the nursing shortage. Nursing economics, 23(1), 6-8.

Laschinger, H. K. S., Finegan, J., \& Wilk, P. (2009). New graduate burnout: the impact of professional practice environment, workplace civility, and empowerment. Nursing Economics, 27(6), 377.

Laschinger, H. K. S., Grau, A. L., Finegan, J., \& Wilk, P. (2010). New graduate nurses' experiences of bullying and burnout in hospital settings. Journal of advanced nursing, 66(12), 2732-2742.

Laschinger, H. K., Leiter, M., Day, A., \& Gilin, D. (2009). Workplace empowerment, incivility, and burnout: Impact on staff nurse recruitment and retention outcomes. Journal of nursing management, 17(3), 302-311.

Laschinger, H. K. S., \& Read, E. A. (2016). The effect of authentic leadership, person-job fit, and civility norms on NGNs' experiences of coworker incivility and burnout. Journal of Nursing Administration, 46(11), 574-580. 
Laschinger, H. K., \& Smith, L. M. (2013). The influence of authentic leadership And empowerment on new-graduate nurses' perceptions of interprofessional collaboration. Journal of Nursing Administration, 43(1), 24-29.

Laschinger, H. K. S., Wong, C. A., \& Grau, A. L. (2012). The influence of authentic leadership on newly graduated nurses' experiences of workplace bullying, burnout and retention outcomes: A cross-sectional study. International journal of nursing studies, 49(10), 1266-1276.

Laschinger, H. K. S., Wong, C. A., \& Grau, A. L. (2013). Authentic leadership, empowerment and burnout: a comparison in new graduates and experienced nurses. Journal of nursing management, 21(3), 541-552.

Laschinger, H. K., Wong, C., Regan, S., Young-Ritchie, C., \& Bushell, P. (2013).

Workplace incivility and NGNs' mental health: The protective role of resiliency. Journal of Nursing Administration, 43(7/8), 415-421.

Lavoie-Tremblay, M., Paquet, M., Duchesne, M., Santo, A., Gavrancic, A., Courcy, F., \& Gagnon, S. (2010). Retaining nurses and other hospital workers: An intergenerational perspective of the work climate. Journal of Nursing Scholarship, 42(4), 414e422. http://dx.doi.org/10.1111/j.15475069.2010.01370.x.

Lavoie-Tremblay, M., Paquet, M., Marchionni, C. (2011). Turnover intention among new nurses. Journal of Nurses Staff Development, 27 (1), 39-45.

Lavoie-Tremblay, M., Wright, D., Desforges, N., Gélinas, C., Marchionni, C., \& Drevniok, U. (2008). Creating a healthy workplace for new-generation nurses. Journal of Nursing Scholarship, 40(3), 290-297. 
Lowe, G. S. (2006). Creating a quality work environment: Results from the Health Sciences Association of Alberta 2006 work environment survey. Edmonton, Alberta: Graham Lowe Group.

MacKinnon, C. A. (1993). Only words. Harvard University Press.

Mayer, R. C., \& Davis, J. H. (1999). The effect of the performance appraisal system on trust for management: A field quasi-experiment. Journal of Applied Psychology, $84,123-136$.

Mayer R.C., Davis J.H. \& Schoorman F.D. (1995) An integrative model of organizational trust. Academy of Management Review 20(3), 709-734.

Mayer, R. C., \& Gavin, M. B. (2005). Trust in management and performance: Who minds the shop while the employees watch the boss? Academy of Management Journal, 48(5), 874-888.

Manojlovich, M., \& DeCicco, B. (2007). Healthy work environments, nurse-physician communication, and patients' outcomes. American Journal of Critical Care, $16(6), 536-543$.

McMullin J.A. \& Cooke M. (2004) Labor Force Ageing and Skill Shortages in Canada and Ontario. Canadian Policy Research Networks Inc, Ottawa, Ontario, Canada

McNamara, S.A. (2012) Incivility in nursing: unsafe nurse, unsafe patients. AORN Journal, 95(4), 535-540.

Namie, G. (2003). Workplace bullying: Escalated incivility. Ivey Business Journal, 68(2), 16.

Oulton, J. A. (2006). The global nursing shortage: an overview of issues and actions. Policy, Politics, \& Nursing Practice, 7(3_suppl), 34S-39S. 
Peus, C., Wesche, J. S., Streicher, B., Braun, S., \& Frey, D. (2012). Authentic leadership: An empirical test of its antecedents, consequences, and mediating mechanisms. Journal of Business Ethics, 107(3), 331-348. doi: 10.1007/s10551-011-1042-3

Regan, S., Laschinger, H. K., \& Wong, C. A. (2016). The influence of empowerment, authentic leadership, and professional practice environments on nurses' perceived interprofessional collaboration. Journal of nursing management, 24(1), E54-E61.

Registered Nurses Association of Ontario (RNAO). (2013). Developing and sustaining nursing leadership best practice guideline (2nd edition). Retrieved from http://rnao.ca/sites/rnao-ca/files/LeadershipBPG_Booklet_Web_1.pdf.

Read, E., \& Laschinger, H. K. (2013). Correlates of new graduate nurses' experiences of workplace mistreatment. Journal of Nursing Administration, 43(4), 221-228.

Ritter, D. (2011). The relationship between healthy work environments and retention of nurses in a hospital setting. Journal of Nursing Management, 19(1), 27-32.

RN.com (2018). Preceptorship: The Vital Role of the Nurse Manager. [pdf] Chicago.: RN.com. Available at: https://lms.rn.com/getpdf.php/1766.pdf. [Accessed 23 Jun. 2018].

Romyn, D., Linton, N., Giblin, C., Hendrickson, B., Limacher, L.M., Murray, C., ... Zimmel, C.M. (2009). Successful transition of the new graduate nurse. International Journal of Nursing Education Scholarship, 6(1), 1-17.

Rush, K. L., Adamack, M., Gordon, J., \& Janke, R. (2014). New graduate nurse transition programs: Relationships with bullying and access to support. Contemporary nurse, 48(2), 219-228.

Russell, K., Hobson, A., \& Watts, R. (2011). The Team Leader Model: an alternative to preceptorship. Australian Journal of Advanced Nursing, 28(3), 5. 
Scott, E. S., Engelke, M. K., \& Swanson, M. (2008). New graduate nurse transitioning: necessary or nice?. Applied Nursing Research, 21(2), 75-83.

Shields, M., \& Wilkins, K. (2006). Findings from the 2005 National Survey of the Work and Health of Nurses. Catalogue no. 83-003-XIE. Ottawa, Canada: Statistics Canada and the Canadian Institute for Health Information.

Schilpzand, P., De Pater, I. E., \& Erez, A. (2016). Workplace incivility: A review of the literature and agenda for future research. Journal of Organizational Behavior, 37, S57-S88.

Shirey, M. R. (2006). Authentic leaders creating healthy work environments for nursing practice. American Journal of Critical Care, 15(3), 256-267.

Spooner-Lane, R., \& Patton, W. (2007). Determinants of burnout among public hospital nurses. Australian Journal of Advanced Nursing, 25(1), 8-16.

Tan, H. H., \& Tan, C. (2000). Toward the differentiation of trust in supervisor and trust in organization. Genetic, Social, and General Psychology Monographs, 126, 241 260.

Vahey, D. C., Aiken, L. H., Sloane, D. M., Clarke, S. P., \& Vargas, D. (2004). Nurse burnout and patient satisfaction. Med Care, 42(2 Suppl.), II57-II66. http://dx.doi.org/10.1097/01.mlr.0000109126.50398.5a

Wei, H., Sewell, K. A., Woody, G., \& Rose, M. A. (2018). The state of the science of nurse work environments in the United States: A systematic review. International Journal of Nursing Sciences, 5(3), 287-300.

Wolff, A., Pesut, B., \& Regan, S., 2010. New graduate nurse practice readiness: perspectives on the context shaping our understanding and expectations. Nurse Education Today, 30(2), 187-191. 
Zauderer, D. G. (2002). Workplace incivility and the management of human capital.

Public Manager, 31,36-43 


\section{CHAPTER 2}

\section{MANUSCRIPT}

\section{Background and Significance}

Nurses play a central role in healthcare organizations because they make a substantial contribution to healthcare delivery through their direct care of patients (Kemppainen, Tossavainen \&Turunen, 2013). Although the qualified nurse workforce is expanding, the Canadian Nurses Association (2009) reported an anticipated shortage of approximately 60,000 registered nurses by 2020 . New graduate nurses (NGNs) entering practice require investment and support in order to prevent a potential nursing shortage. Cho, Laschinger, and Wong (2006) highlighted that to address the nursing shortage, healthcare administrators must focus on recruiting and retaining NGNs. Thus, it is critical that leaders embrace NGNs and ensure they feel engaged in their practice by facilitating inclusive and positive work environments to ensure their effectiveness and well-being. Transition programs tailored specifically to NGNs in terms of resource and supports positively enable their integration (Rush, Adamack, Gordon, \& Janke, 2014); for example, effective leadership and mentorship are essential supports for NGNs to enhance commitment and job satisfaction (Johnstone, Kanitsaki \& Currie, 2008) as well as improving their performance (Clarke \& Springer ,2012; Johnstone, et al.., 2008) Authentic leadership is identified as a relational leadership style needed to facilitate supportive work environments where followers can learn and grow (Wong \& Cummings, 2009). Authentic leaders are characterized by their self-awareness of their own and others' values, knowledge, and strengths; and they are intellectually sensitive to the context in which they lead (Avolio, Gardner, Walumbwa \& Luthans, 2004). By exemplifying these attributes nursing leaders can create constructive relationships, fulfil 
the development needs of NGNs (Scott et al., 2008) and positively enhance workplace trust through effective and supportive communication (Neider \& Schriesheim, 2011).

The quality of relationships between staff nurses and their managers is critical to building a healthy work environment (Lewis \& Malecha, 2011). "Healthy work environments for nurses are defined as practice settings that maximize the health and well-being of the nurse, quality patient/client outcomes, organizational performance and societal outcomes" (Registered Nurses Association of Ontario [RNAO], 2013, p. 8). Such settings contribute to high job satisfaction and effective performance of nurses by enhancing mutual trust between managers and staff nurses (Kramer \& Schmalenberg, 2008). According to the Nursing Advisory Committee (2002) a sustainable and healthy work environment is created through strong, positive nursing leadership that facilitates an atmosphere of trust. Authentic leaders who genuinely share information with others and listen to followers are more likely to increase trust in the organization, supervisors and co-workers (Coxen, van der Vaart \& Stander, 2016) and thus enhance higher work engagement (Wong, Laschinger, and Cummings, 2010). As role models, leaders who display trustworthiness behaviours such as integrity, support and competence are more apt to evoke trust in coworkers and the organization (Coxen et al., 2016; Mayer \& Gavin, 2005). Laschinger and Finegan (2005) reported a significant association between nursing staff's trust in their managers and feeling respected and secure in healthcare settings.

Workplace trust is one important consequence of authentic leadership (ClappSmith, Vogelsang, \& Avey, 2009). Effective and collaborative relationships between managers and their followers are based on mutual trust, and respect (Kramer \& Schmalenberg, 2008). Trustworthy leaders maintain positive expectations through words and actions and by opening up opportunities for their followers (Appelbaum et al., 2004). 
Trust in nursing management is achieved when leaders respectfully listen to employees, appreciate their efforts (Ferres \& Travaglione 2003), and consider followers' needs in decision-making (James, 2011). Staples's (2001) study targeted employees of North American technological organizations where study results showed a strong relationship between an employee's trust in their manager and higher self-perceptions of performance, higher job satisfaction and low job stress. In nursing, few studies have linked trust in managers to organizational outcomes; however, nurses' structural empowerment has been associated with greater trust in managers which in turn positively influenced organizational commitment (Laschinger, Finegan, Shamian, Casier, 2000), job satisfaction and perceptions of care quality (Laschinger, Finegan, Shamian, 2001). A meta-analysis conducted by Colquitt, Scott, and LePine (2007) showed that trust in managers was associated with fewer counterproductive behaviours in the workplace meaning individuals who are willing to trust others commit fewer destructive behaviours such as incivility, aggression, lateness, and absenteeism

Incivility is an example of a growing issue harming relationships in the workplace. Andersson and Pearson (1999) defined incivility as "low intensity deviant behaviour with ambiguous intent to harm the target, in violation of workplace norms for mutual respect" (p. 457). Recently, reported increased incivility in healthcare settings poses a threat to nurse well-being and patient safety (Kaiser, 2017). Incivility also causes distrust in management (Pearson \& Parath, 2000) and has been reported from three sources: physicians, supervisors, and coworkers (Laschinger, Wong, Regan, YoungRitchie \& Bushell, 2013). Although supervisor incivility is less frequent than other sources, it has been linked to poor mental health (Laschinger, eal., 2013) and lower nursing productivity and commitment (Lewis \& Malecha, 2011). A qualitative study of 
incivility experiences of NGNs showed $10 \%$ of the participants witnessed disrespect from their leaders; they also described leader behaviours such as not fulfilling their promises, shouting at staff in front others, making false accusations as well as unfairly treating their staff (Kerber, Woith, Jenkins \& Astroth, 2015). Uncivil behaviours negatively influence staff leader-nurse relationships (Harris, 2011) by showing disrespect toward others and marginalizing them within their group (Embree \& White, 2010). Similarly, nurses experiencing workplace incivility feel uncomfortable communicating with their managers, and will stay disconnected from their workplace, which will eventually impact their performance and work engagement. Experiencing incivility damages interpersonal relationships due to feelings of failure, isolation and loss (Harris, 2011). Also, Harris (2011) claimed that nurses who experience workplace incivility produce a lower quality of care, put less effort into their daily tasks, and show less loyalty to their employer and may even feel forced to quit their jobs.

Authentic leadership positively influences the effectiveness of organizations and outcomes by establishing effective communication and healthy relationships through civil and respectful interactions with followers (Men \& Stacks, 2014). Leaders who are perceived as authentic are able to reflect their core values in their communications, consider others' opinions when making decisions, demonstrate ethical standards in their behaviour, encourage open communication and convey a priority for transparency in their relationships with others (Avolio et al., 2004). Specifically, authentic leaders show transparency by being honest and maintaining integrity (Walumbwa, Avolio \& Gardner, 2008) resulting in staff trust in and respect for the leader (Laschinger, Leiter, Gilin-Oore \& Mackinnon, 2012). 
Leaders have a responsibility to identify and support the needs of NGNs and advocate for them (Morrow, 2009). Dyess and Sherman (2009) highlighted that NGNs deserve visibility and transparency from their leaders. However, manager incivility has been increasingly reported by nurses (Kerber, et al., 2015). In fact, NGNs have reported negative reactions from supervisors when they seek consultation for complex issues (Bowles \& Candela, 2005; Kelly \& Ahern, 2009). Importantly, subtle attitudes and behaviours from managers can minimize staff trust in management (Sypher \& Gill, 2009). Leaders' mistreatment toward NGNs may result in unhealthy relationships and distrust. Moreover, incivility between NGNs and their leaders may negatively affect the quality of patient care. McNamara (2012) explained that workplace incivility leads to disgruntled, hostile, and preoccupied nurses, which ultimately minimizes the quality of patient care and puts patients at risk for adverse effects.

Although limited research has been conducted to examine uncivil behaviour of managers toward NGNs, and limited nursing research linking authentic leadership with trust in managers (Wong et al., 2010), it is vital that the relationship between manager incivility and NGNs' trust in their managers be investigated. Therefore, the purpose of this study is to examine the relationships among authentic leadership of managers, NGNs' experiences of manager incivility and trust in their managers. The findings of this study may benefit nursing leaders and managers in developing and implementing theoryand evidence-informed strategies to improve working communication and relationships between managers and NGNs which will subsequently enhance successful transition of NGNs to practice and the delivery of quality patient care. Findings may also identify how authentic leaders' behaviours influence NGNs' trust in their managers and the extent to which they experience incivility from their managers. In addition, study results may 
encourage organizations to invest in authentic leadership training programs that focus on providing frontline managers with skills and tools that allow them to establish positive and trusting relationships with their staff.

\section{Theoretical Framework}

Even though authentic leadership theory is a relatively new leadership theory (Walumbwa et al., 2008), many studies have tested elements of the theory and linked authentic leadership to a variety of workplace variables, leading to a growing body of evidence and support for the theory (Gardner, Cogliser, Davis, \& Dickens, 2011). The concept of authenticity within the leadership literature was noted in the 1960s (Novicevic, Harvey, Buckley, Brown \& Evans, 2006) and observed in the writings of Maslow (1968) and Rogers (1961). In 2004, authentic leadership theory was more fully articulated by Avolio et al (2004) and authentic leadership was described as the root component of effective leadership. Using a nursing lens, the principle of authentic leadership has the potential to contribute to the development of healthy work environments through increasing trust and reducing nurse turnover (Avolio and Gardner, 2005; Kerfoot, 2006; Shirey, 2006). Authentic leadership is defined as a "pattern of transparent and ethical leader behavior that encourages openness in sharing information needed to make decisions while accepting followers' inputs" (Avolio, Walumbwa and Weber, 2009, p. 423). Leaders who are truly authentic are able to align their actions with their core values, and act with integrity (Avolio et al., 2004).

Authentic leaders can positively influence work environments through four components which are: self-awareness, balanced processing, internalized moral perspective, and relational transparency. The first component, self-awareness, refers to the process of understanding of one's unique features such as talents, strengths, values, 
motives and beliefs. It involves introspective self-reflection and the constant reassessment of one's self-concept through feedback from others (Peus, Wesche, Streicher, Braun, \& Frey, 2011). Authentic leaders have a clear sense of who they are, including, knowing their personal strengths and weaknesses, and how they impact others. They are able to re-evaluate other's opinions about important issues, and encourage feedback from followers to improve interpersonal relationships (Walumbwa et al., 2008). The second component, balanced processing, is a process of "self-esteem-relevant and non-selfesteem relevant information; that is, they are able to more objectively evaluate and accept both positive and negative aspects, attributes and qualities of themselves" (Gardner, Avolio, Luthans, May \& Walumbwa, 2005, p.356). Authentic leaders are able to objectively analyze information, be considerate of others' opinions in making decisions, and maintain fairness by exploring an opponent's viewpoint before taking any actions. The third component, internalized moral perspective, is the process of acting in accordance with one's values and beliefs rather than acting to please others, receive rewards or avoid punishment (Gardner et al., 2005). Authentic leaders are guided by their morals and values rather than external influences such as organizational pressures. Authentic leaders' actions are consistent with their self-concept to make right and ethical decisions (Hannah, Lester \& Vogelsang, 2005) and they encourage others to take stands that reflect their core values as well (Walumbwa et al., 2008). The final component, relational transparency, is defined as presenting one's genuine self through openness and appreciation of others' values and emotions (Walumbwa et al., 2008). Leaders show transparency by openly sharing information, feeling, and interacting with others in a genuine and inclusive manner (Walumbwa et al., 2008). 
Authentic leaders influence followers' behaviours and attitudes through the process of identification with the people they lead which involves personal and social identification (Avolio et al., 2004). Personal identification refers to a process whereby the follower's belief about the leader is "self-referential or self-defining" (Kark \& Shamir, 2002). Authentic leaders engage in leading by example (i.e. role modeling) and through this others may come to identify on a personal level with the leader. Leaders' identification with their followers is achieved by encouraging open communication, sharing similar values and providing constant motivation (Avolio et al., 2004). Social identification is described as "the individual's knowledge that he/she belongs to certain social groups together with some emotional and value significance to him/her of this group membership" (Tajfel, 1974. p. 292). Leaders' ethical behaviour strongly affects what followers attend to, and what they think, how they conduct their roles, and how they behave with others; therefore, through introspective self-reflection, leaders are able to maintain moral standards and keep their followers engaged which ultimately enhances teamwork (Avolio et al., 2004).

Authentic leadership is important to sustain leader-follower relationships through four concepts (hope, trust, positive emotions and optimism) which contribute to achieving positive organizational outcomes (Avolio et al., 2004). In this study, trust is the concept of interest. Trust is defined as a" psychological state comprising the intention to accept vulnerability based upon positive expectations of the intentions or behavior of another" (Rousseau,1998. p. 395). Authentic leaders can create a culture of benevolence and integrity by effectively listening to the followers' perspective and feelings and being considerate to their opinion before making decisions, all leading to realistic healthy relationships (Avolio et al., 2004). In addition, employees who trust their leader are more 
likely to adopt positive attitudes toward their work and engage in positive behaviour which contributes to sustained organizational performance (Avolio et al., 2004). In summary, authentic leadership contributes to enhanced healthy relationships between followers and leaders, and it influences followers' attitudes, behaviors, and ultimately work outcomes.

\section{Literature Review}

The databases, CINAHL, SCOPUS, and Google Scholar, were utilized to conduct the literature review. The search also included references from published peer reviews and scholarly full text articles, dissertations, and theses from 2004 to 2017. The key words used were "authentic leadership" combined with "workplace incivility", "new graduated nurses" combined with "workplace incivility", "authentic leadership" combined with "trust in manager", and "workplace incivility" combined with "trust in manager". In the following section, the literature concerning theory and research related to authentic leadership, incivility, and trust in the manager are outlined. A brief summary which highlights the significant associations among these concepts and gaps in the existing literature is provided. A hypothesized model was developed for the research study using authentic leadership theory as the foundation (Avolio et al., 2004) to describe relationships among authentic leadership of managers, manager incivility and NGNs' trust in their managers.

\section{Authentic Leadership}

Recently, there has been a proliferation of empirical studies examining authentic leadership that provide support for the mechanisms by which it enhances followers' attitudes and behaviours (Gardner, et al., 2011). Authentic leaders are not only concerned with their personal authenticity but also with their efforts to transmit this authenticity in 
the workplace to influence followers' behaviour and attitudes (Clapp-Smith et al., 2009). Authentic leadership theory asserts the developmental behaviours that leaders should display in order to generate the trust and respect of others (Avolio et al., 2004;

Walumbwa et al., 2008).

Moreover, authentic leadership has been linked to a variety of outcomes in different disciplines (Gardner et al., 2011). A quantitative study designed to investigate the relationship between authentic leadership, trust in managers, psychological capital, and performance among 89 employees of Midwestern retail clothing stores in United States found that authentic leadership was significantly associated to trust in management $(\beta=.21, p<.05)$ and change in unit sales performance $(\beta=.30, p<.05)$ and trust was a mediator of the relationship between authentic leadership and sales performance (ClappSmith, et al., 2009). Findings of an Iranian study (Darvish \& Rezaei, 2011) of employees $(n=80)$ who worked at telecommunication companies demonstrated that authentic leadership was positively associated with followers' job satisfaction $(r=0.786, p<.01)$ and team commitment $(r=.716, p<.01)$. Moreover, Wang and Heish's (2013) study of Taiwanese manufacturing employees $(n=386)$ showed that authentic leadership was positively and significantly related to employee trust in management $(r=.80, p<.01)$, and employee engagement $(r=.58, p<.01)$ and trust in management had a positive significant correlation with work engagement $(r=.64, p<.01)$.

A survey of 402 employees of business corporations in the United States was conducted to examine the relationship between authentic leadership, symmetrical and transparent communication, and employee relational outcomes (Men \& Stacks, 2014). Symmetrical communication refers to" the willingness of an organization to listen and respond to the concerns and interests of publics" (Men \& Stacks, 2014, p. 304). The 
results of this study showed authentic leadership positively affected symmetrical communication and transparent communication which supported that authentic leadership had a central role in constructing organizations' communication systems and driving successful internal communications. Another cross-sectional survey of healthcare (included nurses) sector employees $(n=633)$ in South Africa revealed that authentic leadership significantly influenced trust in the organization $(\beta=.60, p<.01)$, immediate supervisor $(\beta=.82, p<.01)$ and coworkers $(\beta=.48, p<.01)$ and also had an indirect effect on organizational citizenship behaviour through trust in the organization $(\beta=.17, p$ $<.01)$ and trust in coworkers $(\beta=.11, p<.05)$ (Coxen et al., 2016).

In the nursing literature, authentic leadership has been related to several work outcomes of NGNs. A predictive non-experimental survey designed to study the relationships between Ontarian NGNs' $(\mathrm{n}=170)$ perceptions of preceptor authentic leadership and work engagement and job satisfaction indicated that authentic leadership had a positive effect on NGN work engagement $(r=.21, p<.01)$ which partially mediated the relationship between authentic leadership and job satisfaction (Giallonardo, Wong, \& Iwasiw, 2010). Fallatah and Laschinger's (2016) findings using a sample of 93 NGNs highlighted that authentic leadership was significantly correlated to supportive professional practice environments $(\beta=.42, p<.001$ and job satisfaction $(\beta=.16, p<$ .001). The relationship between authentic leadership and job satisfaction was partially mediated by supportive professional practice environments. These findings suggest that authentic leadership may be essential to create a supportive environment which contributes to building trustworthy and healthy relationships.

Results of another secondary analysis examining the relationship between authentic leadership on interprofessional collaboration (IPC) among 342 NGNs, showed 
that the authentic leadership of managers was significantly related to higher NGNs' perceptions of the quality of IPC on their units $((\beta=.294, p<.05$; Laschinger \& Smith, 2013). Interprofessional collaboration (IPC) has been associated with increased trust in team members, cooperation and knowledge exchange with colleagues (Gaboury, Lapierre, Boon, Moher, 2011). A longitudinal study aimed to examine the effects of authentic leadership, structural empowerment, and relational social capital on NGNs' mental health and job satisfaction in sample of 191 NGNs found that authentic leadership was positively significantly associated with structural empowerment $(\beta=.50, p<.05)$, relational social capital $(\beta=.70, p<.05)$, job satisfaction $(\beta=.50, p<.05)$, and a negative indirect effect on mental health symptoms $(\beta=.21, p<.05)($ Read \& Laschinger, 2015). The results of these studies highlight that authentic leadership was related to positive work outcomes and internal communication and collaboration suggesting that authentic leaders may successfully maintain trustworthy relationship between managers and their followers.

Authentic leadership style has been shown to be inversely related to negative behaviours in workplace such as bullying; however, there are few studies that have examined the relationship between authentic leadership and manager's incivility. Read and Laschinger (2013) examined the relationships among psychological capital and organizational characteristics including authentic leadership and uncivil behaviour experienced by NGNs $(\mathrm{n}=342)$ across Ontario. New graduate nurses reported a low level of incivility, that is, they experienced workplace incivility less than once or twice per week from their supervisor $(M=1.33, S D=.56)$. Notably authentic leadership was significantly negatively correlated to supervisor incivility $(r=-.32, p=<.05)$. These results highlighted supervisor incivility may increase when there is low levels or an 
absence of authentic leadership. Leaders demonstrating an authentic leadership style maintain a respectful attitude toward followers and promote a culture of respect. Moreover, empirical research has shown that authentic leadership had a negative relationship with workplace bullying. Although bullying is a more extreme form of incivility, there is some effect of authentic leadership on workplace bullying. The results of a cross-sectional survey of 342 of NGNs showed that authentic leadership had a significant negative direct impact on bullying $(\beta=-.34, p=.001)$ (Laschinger, Wong, \& Grau, 2012).

A cross-sectional study conducted by Laschinger and Read (2016) aimed to test the effect of authentic leadership, person-job-fit, and civility norms on coworker incivility experienced by NGNs $(n=993)$. Civility norms are defined as accepted rules that form mutually respectful treatment and behavior towards others (Walsh, et al. 2012). Importantly, authentic leadership was positively related to civility norms $(r=.37, p<$ .05). Structural equation modelling results supported that authentic leadership of managers positively contributed to NGNs' perceptions of civility norms in their units and consequently, reduced co-worker incivility. Previous findings show that managers who display authentic leadership behaviours are able to minimize negative behaviours in the workplace that lead to negative outcomes such as burnout and emotional exhaustion. Therefore, authentic leadership may be an effective approach to reduce manager incivility, and enhance trust in management.

\section{Incivility}

Although there are similarities between incivility and other forms of organizational misconduct, such as bullying or cynicism, incivility can be distinguished in three ways (Pearson \& Porath, 2004). First, incivility is inappropriate behavior towards 
individuals not the organization. Second, it involves minor acts such as ignoring or disrespecting. Third, incivility is not meant to harm (Pearson \& Porath, 2004, Robinson \& Bennett, 1995). Incivility may or may not involve power, is not typically intentional, and tends to be less persistent that other forms of negative behavior such as bullying (Hershcovis, 2011). There is agreement in the literature that the intention of causing harm distinguishes incivility from other forms of violence such as bullying (Felblinger, 2008). However, the lack of intention of harm does not guarantee that the harm will not happen (Estes \& Wang, 2008).

A qualitative study was aimed to obtain a rich description of the perceptions of 79 nurses with two years of experience, exposed to workplace incivility at a Midwestern University in the United States. Kerber, Woith, Jenkins and Astroth (2015) showed almost half of the participants experienced disrespect from their leaders. The findings highlighted important themes involving "the lack of respect from nurse managers" (Kerber et al., 2015, p.525). Under this theme, eight participants described uncivil behavior from managers such as yelling at staff in front of others, making false accusations, and refusing to apologize when they have unfairly treated others. Importantly, $11 \%$ of the participants reported that they had to leave their job because of incivility. These findings were consistent with Kelly and Ahern's (2009) study results of NGNs experiences during their first six months of employment as registered nurses. The findings showed that various forms of incivility included silence in response to communication, feeling like an outsider, and unwelcoming attitudes from other staff all of which impeded the socialization process during the first six months and led to attrition.

Regan, et al. (2017) studied the transition experience of Canadian NGNs by examining the perceptions of NGNs $(n=42)$ and unit managers $(n=28)$. This qualitative 
study's results revealed that feeling supported and safe were crucial factors that facilitated the transition of NGNs from student to professional life. The participants emphasized the importance of the quality of relationships with people surrounding them in early stages of their nursing career. When the participants were asked to speak about the challenges they encountered in their first two years of work, they indicated incivility and intimidation were the main issues hindering them from smoothly going through the critical transition process. Thus, this study's findings highlighted that workplace incivility significantly impacts NGNs in their first two years of work experience.

A survey of 272 NGNs carried out by Laschinger, Wong, Regan, Ritchie, and Bushell (2013) aimed to investigate the relationship between all sources of workplace incivility (coworkers, physicians, supervisors), and the mental health status of NGNs and the role of personal resilience. Participants reported that the greatest source of incivility was coworkers ( $M=1.7, S D=.73$ ) whereas supervisor incivility was the least and less frequent $(M=1.3, S D=0.58)$. Not surprisingly, all forms of incivility were significantly positively associated with poor mental health, particularly co-worker incivility, which had the strongest correlation $(r=.36, p<.05)$. Incivility was a significant independent predictor $(\beta=.30, p<.05)$ of poor mental health of NGNs. As shown in this study, all forms of workplace incivility negatively influenced the mental health of NGNs and threaten their transition to practice.

A cross-sectional survey of 350 employee working in different organizations in Midwestern USA was aimed to study the impact of supervisors' incivility on subordinates' tasks and citizenship performance through work engagement and this mediated relationship was conditional on the influence of trust in the supervisor (Jawahar $\&$ Schreurs, 2018). The results of this study suggested that the relationship between 
supervisor incivility and work engagement was negatively related to trust in the supervisor. Thus, Jawahar and Schreurs' (2018) findings highlighted the effect of incivility on followers' trust in their supervisors.

\section{Trust in Manager}

Trust is a primary constructs of authentic leadership theory in that authentic leaders are able to positively influence follower attitudes and work behaviours through trust (Beddoes-Jones \& Swailes, 2015). Trust is defined as a psychological state that involves an individual's willingness to be vulnerable to another individual's actions without the ability to control or monitor that individual's behaviours (Mayer, Davis, \& Schoorman, 1995). Avolio and Gardner (2005), emphasized that maintaining integrity and being able to engage in balanced processing contributes to respectful and trustworthy leader-subordinate relationships. When authentic leaders demonstrate a high standard of morals, integrity, and honesty, they gain a positive reputation that fosters positive expectations among their followers, as well as enhances followers' trust and willingness to collaborate with their leader for accomplishing organization goals (Avolio et al., 2004). A leader that is perceived as more authentic can increase trust in their followers, resulting in higher confidence, achieving work goals, and improving performance (Laschinger et al., 2012). They also can create an environment that increases hope and optimism for the future which allows followers to think positively, strengthen their skills, enhance performance, and increase awareness of morally related decisions (May, Chan Hodges \& Avolio, 2003).

Researchers have asserted that mutual trust between managers and their followers is necessary to maintain ongoing cooperative relationships (Anderson \& Weitz, 1989; Whitener, Brodt, Korsgaard, \& Werner, 1998). However, distrust in the manager may 
limit their influence on subordinate performance and organizational citizenship behaviors (Brower, Lester, Korsgaard, Dineen, 2009). Lack of trust in managers contributes to dissatisfying work environments (Pierce \& Gardner, 2004) as well as increasing a subordinate's tendency to leave his/her job (Brower, et al.,2009). Mayer and colleagues (2005) found that lack of trust in management may hinder the efforts to direct employees' attention and stay focused on their work. If the employees do not trust their managers, their cognitive resources will be diverted to non-productive issues focusing on selfprotection (Deming, 1994) or “defensive behaviors" (Ashforth \& Lee, 1990, p. 629)

Wong and Cummings (2009) carried out a secondary analysis aimed to examine a model linking authentic leadership behaviours with trust in management and healthcare outcomes among two groups of personnel (clinical $n=147$ and nonclinical $n=188$ ) of healthcare professionals of a western Canada healthcare agency. Registered nurses were included in a sample of direct care providers in this study; however, their years of experience were not identified. The findings indicated that there were significant relationships between supportiveness of leaders and supportive group $(\beta=.50, p=.01)$ and between supportive group and trust $(\beta=.30, p=.01)$. Also, there were no significant direct effects between specific authentic leadership and trust in management, but the indirect effect from supportiveness behaviour to trust through a supportive group was significant $(\beta=.15, p=.05)$. These findings indicated that leaders' behaviours (supportiveness) influences followers' perceptions of trust in management.

Non-experimental survey research conducted by Wong, Laschinger, and Cummings (2010), was aimed to test a model linking authentic leadership with nurses' trust in their managers, voice behaviour and their perceptions of the quality of unit care in a study of 280 registered nurses in Ontario. The results showed that authentic leadership 
was significantly directly associated with trust in the manager $(\beta=.43, p<.001)$, and had an indirect effect on trust $(\beta=.26, p<.001)$ through personal identification with the manager. Overall, the findings supported the hypothesized model and authentic leadership theory's assumptions; particularly, significant effects (direct and indirect) between authentic leadership and trust in managers through personal identification. Nevertheless, this study's sample was experienced registered nurses with more than two years of experience.

The objective of another secondary analysis conducted in Ontario by Wong and Giallonardo (2013), was to test the hypothesized model connecting authentic leadership with trust, areas of worklife, and nurses' perceptions of adverse patient outcomes; the final sample size was 280 registered nurses. The results supported the proposed relationships in that both trust and areas of work life mediated the relationship between authentic leadership and nurses' perceptions of adverse patient outcomes. Importantly, authentic leadership had a significant and strong positive effect on trust in the manager ( $\beta$ $=.69, p<.001$ ). This finding suggest authentic leadership fosters a high level of trust in the managers. However, the sample was experienced nurses not NGNs.

Using convenience sampling involving 633 employees working in the public healthcare sector in South Africa, Coxen, Van der Vaart, and Stander (2016) examined the effect of authentic leadership on organizational citizenship behaviour. Findings showed authentic leadership significantly influenced trust in all three referents: organization $(\beta=.60, \mathrm{p}<0.01)$, supervisor $(\beta=.82, p<.01)$, and co-workers $(\beta=0.48, p$ $<0.01)$. Trust in the organization and co-worker were positive and significant predictors of organizational citizenship behaviour. Additionally, authentic leadership was found to have an indirect significant influence on organizational citizenship behaviour through 
trust in the organization and co-workers; surprisingly, authentic leadership did not significantly affect organizational citizenship behaviour through trust in the immediate supervisor. Coxen et al., (2016) justified the reasons behind this result may be because managers do not perform shift work and do not work closely enough with professionals. However, this study's population was a mixed sample of health professionals that included some nurses and therefore, the result may not be generally applicable to nurses particularly NGNs.

\section{Summary of the Literature}

Authentic leadership was found to have a significant relationship with a variety of outcomes in business including symmetrical communication and transparent communication, trust in the organization and managers, sales performance, work engagement and organizational citizenship behaviour. In the nursing literature, authentic leadership was positivity associated with NGNs' work engagement, job satisfaction, supportive professional practice environments, and interprofessional collaboration. Whereas, it has been negatively correlated with bullying and burnout. A few quantitative and qualitative studies suggested that authentic leadership was significantly negatively associated with supervisor incivility which also affects new nurses' well-being such as mental health. Studies have shown that authentic leadership was positively related to trust in managers. However, most of the studies in which authentic leadership and trust were examined sampled experienced nurses. Limited studies have addressed relationships between authentic leadership of managers and NGNs' experience of manager incivility and trust. No studies were found addressing the relationships among authentic leadership workplace incivility from managers and trust in managers.

\section{Hypotheses and Rationale}


Based on the preceding literature review and Avolio et al.'s (2004) authentic leadership theory, the following hypotheses and model (see Figure 1) were generated:

1. Authentic leadership is negatively associated with manager incivility which in turn is negatively associated with trust in the manager.

2. Authentic leadership is directly positively associated with trust in the manager.

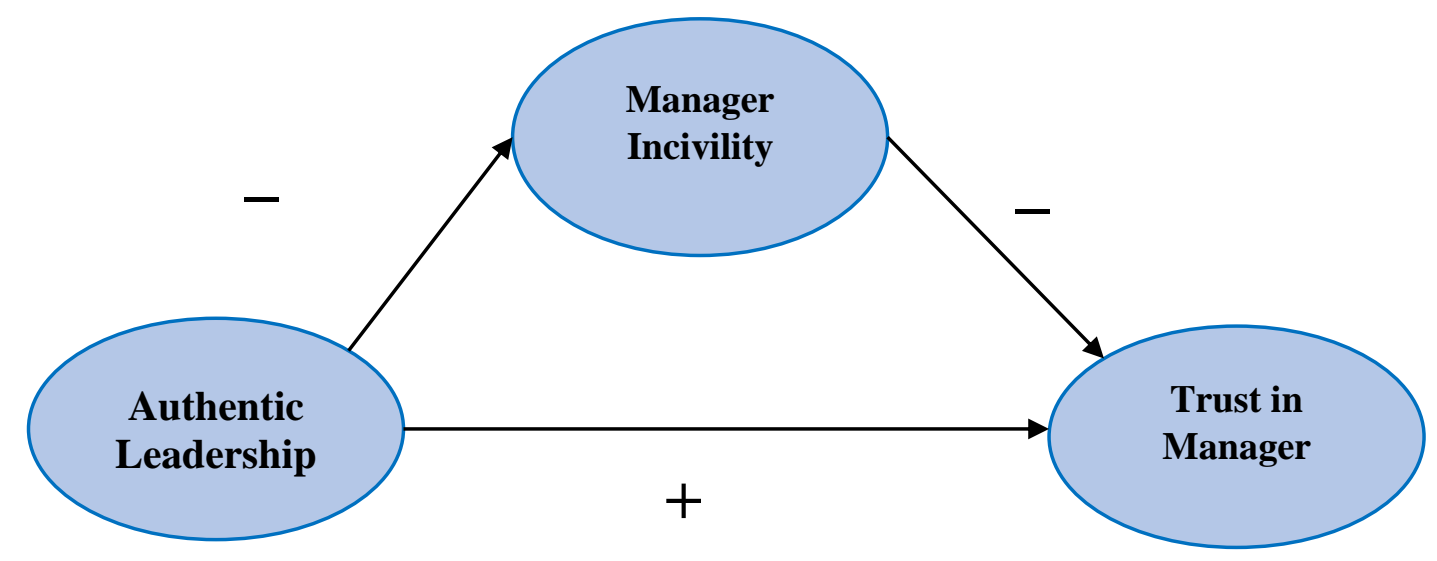

Figure 1: Hypothesized model

\section{Rationale for the Hypotheses}

Authentic leaders influence their followers' attitudes and behaviours. Authentic leadership emphasizes the consistency of action with deep personal beliefs and values that develop credibility, respect and trust between leaders and their followers by building effective collaboration, enhancing open and free communication (Avolio et al.,2004). Authentic leaders appreciate employees' values, respect individuals' differences and accept diverse viewpoints. They are able to discover individual's talent and create motivation to strengthen these talent (Laschinger et al., 2012). Trust is a primary outcome of authentic leadership, and thus, trust in the manager may change as the leader deviates from the principles of authentic leadership. According to Mayer et al. (1995), placing 
greater or less trust in another party is based on the attitude and behaviour of the leaders. Leaders who are characterized by honesty, integrity, dependability, fairness and ability foster positive experiences with managerial interactions and enhances a high level of trust and facilitates cooperation with leaders. In contrast, uncivil attitudes and mistreatment from managers are perceived as workplace stressors which have a negative effect on NGNs' trust in their managers (Laschinger \& Fida, 2014). As a result, nursing leaders are likely to lose trust from NGNs.

\section{Method}

\section{Design}

Secondary analysis of the baseline data from a two-wave national study of Canadian NGNs study entitled, Starting Out: A time-lagged Study of New Graduate Nurses' Transition to Practice (Laschinger et al., 2016) was conducted. This study's design was a non-experimental, descriptive correlational design. Ethical approval was received from the University of Western Ontario Ethics Review Board for Health Sciences Research in June 2012.

\section{Sample and Setting}

The Time 1 sample of the study was obtained using disproportionate random sampling. In order to obtain the desired sample size of 200 NGNs from each province, with an anticipated 50\% response rate, at least 400 NGNs were required from each provincial regulatory body in Canada (Laschinger, et al., 2016). At Time 1, 3,906 surveys were mailed to NGNs, and of these 3743 were eligible for the study, and 1020 returned completed questionnaires for a response rate of $27.3 \%$.

The inclusion criteria for this study included male and female NGNs who, at the time of the study (2013), had graduated since September 2011, with 12 to 24 months of 
experience, and were registered with one of the ten provincial regulatory bodies for registered nurses in Canada (Laschinger, 2013). Registered practical nurses, clinical educators, managers, and registered nurses who were on a leave of absence were excluded from this study. The inclusion criteria of this data were suitable to answer the question of the current study.

A power analysis was conducted to determine the appropriate sample size for this secondary analysis. Based on an alpha of 0.05 , two predictors, and power level of 0.80 , the calculation revealed that 68 participants were needed to calculate a moderate effect size (0.15). Therefore, the sample size of 1020 participants was more than sufficient for the current study.

\section{Sample Characteristics}

Demographic data are presented in Table 1. The majority of the sample were female $(n=934,91.6 \%)$ with a mean age of 27.44 years and most NGNS were from Ontario ( $n=216,21.2 \%)$ followed by British Columbia $(n=153,15 \%)$. Most registered nurses had a bachelor's degree $(n=942,4 \%)$ and worked full time $(n=618,60.6 \%)$. Almost half of NGNs worked in medical surgical units (49.9\%) followed by critical care $(17.9 \%)$ and maternal-child units (10.2\%). The average number of years of experience as a registered nurse was 1.20 years $(S D=.52)$, and NGNs worked at their current organization for an average of 1.10 years $(S D=.55)$, and on their current unit for an average of .95 years $(S D=.52)$.

\section{Instruments}

A demographic survey and three standardized self-report instruments were used to measure the three variables of interest: authentic leadership, manager incivility and trust in managers. 
Table 1

Demographic Characteristics of Sample $(N=1020)$

\begin{tabular}{|c|c|c|c|c|c|}
\hline \multicolumn{4}{|l|}{ Demographics Data } & $\begin{array}{l}\text { Frequency } \\
\text { (n) }\end{array}$ & Percentage $(\%)$ \\
\hline \multirow[t]{2}{*}{ Gender } & \multicolumn{3}{|c|}{ Female } & 934 & 91.6 \\
\hline & \multicolumn{3}{|l|}{ Male } & 76 & 7.5 \\
\hline \multirow[t]{3}{*}{ Education } & \multicolumn{3}{|c|}{$\mathrm{BScN}$} & 942 & 92.4 \\
\hline & \multicolumn{3}{|c|}{ Master degree } & 3 & 0.3 \\
\hline & \multicolumn{3}{|c|}{ College nursing diploma } & 71 & 7.0 \\
\hline \multirow[t]{3}{*}{ Employment Status } & \multicolumn{3}{|c|}{ Full time } & 618 & 60.6 \\
\hline & \multicolumn{3}{|c|}{ Part time } & 288 & 28.2 \\
\hline & \multicolumn{3}{|c|}{ Casual } & 108 & 10.6 \\
\hline \multirow[t]{8}{*}{ Specialty area } & \multicolumn{3}{|c|}{ Med-Surgical } & 509 & 49.9 \\
\hline & \multicolumn{3}{|c|}{ Critical care } & 183 & 17.9 \\
\hline & \multicolumn{3}{|c|}{ Maternal-child } & 104 & 10.2 \\
\hline & \multicolumn{3}{|c|}{ Mental health } & 61 & 6.0 \\
\hline & \multicolumn{3}{|c|}{$\begin{array}{l}\text { Float pool or nursing } \\
\text { resources }\end{array}$} & 39 & 3.8 \\
\hline & \multicolumn{3}{|c|}{ Community health } & 59 & 5.8 \\
\hline & \multicolumn{3}{|c|}{ Long term care } & 45 & 4.4 \\
\hline & \multicolumn{3}{|c|}{ Geriatric/ Rehab } & 12 & 1.2 \\
\hline \multirow[t]{11}{*}{ Province } & \multicolumn{3}{|c|}{ Alberta } & 141 & 13.3 \\
\hline & \multicolumn{3}{|c|}{ Quebec } & 61 & 6.0 \\
\hline & \multicolumn{3}{|c|}{ Saskatchewan } & 83 & 8.1 \\
\hline & \multicolumn{3}{|c|}{ British Columbia } & 153 & 15.0 \\
\hline & \multicolumn{3}{|c|}{ Prince Edward Island } & 31 & 3.0 \\
\hline & \multicolumn{3}{|c|}{ New Brunswick } & 22 & 2.2 \\
\hline & \multicolumn{3}{|c|}{ Manitoba } & 123 & 112.1 \\
\hline & \multicolumn{3}{|c|}{ New Brunswick } & 55 & 5.4 \\
\hline & Newfo & undland & & 52 & 5.1 \\
\hline & Nova & Scotia & & 83 & 8.1 \\
\hline & Ontari & & & 216 & 21.2 \\
\hline Demographics Data & $\mathrm{N}$ & Minimum & Maximum & M & $\mathrm{SD}$ \\
\hline Age & 1020 & 21 & 59 & 27.44 & 6.34 \\
\hline Years as RN & 1020 & 0.00 & 3.00 & 1.20 & 0.52 \\
\hline $\begin{array}{l}\text { Years in } \\
\text { organization }\end{array}$ & 1020 & 0.00 & 5.00 & 1.10 & 0.55 \\
\hline $\begin{array}{l}\text { Years in current } \\
\text { unit }\end{array}$ & 1020 & 0.00 & 3.00 & 0.95 & 0.52 \\
\hline
\end{tabular}


Authentic leadership. The Authentic Leadership Questionnaire (ALQ) (Avolio, Gardner \& Walumbwa, 2007) was used to measure NGNs' perceptions of their immediate manager authentic leadership. This is a 16-item Likert scale that consists of four subscales: relational transparency (5 items), internalized moral perspective (4 items), balanced processing ( 3 items), and self-awareness ( 4 items). All of the items are rated on a scale of 0 meaning "not at all" to 4 referring to "frequently, if not always". Cronbach alphas ranged from 0.70 to 0.90 (Walumbwa et al., 2008) which is considered excellent measurement reliability (Polit, 2017). Construct validity was assessed using confirmatory factor analysis and supported the four components factor structure of the scale (Walumbwa et al. (2008).

Manager incivility. The Straightforward Incivility Scale (SIS) developed by Leiter and Day (2013) was used to assess the frequency of uncivil behaviour from managers; for example, item 1 asked "whether a supervisor ignored you". The SIS is divided into three subscales; supervisor incivility, co-worker incivility and physician incivility but only the supervisor subscale was used in this study. Each subscale has five items using a scale which ranges from 0 (Never) to 6 (Daily). The SIS scale reliability has a reported Cronbach's alpha of .90 for supervisor incivility. Construct validity was assessed by using confirmatory factor analysis which supported the three-factor structure of the scale (Leiter \& Day, 2013; Portoghese et al., 2015).

Trust in manager. Trust in the manager was measured using a modified seven item version of a scale used by Norman, Avolio and Luthans (2010) who had adapted Cummings and Bromiley's (1996) 12-item organizational trust inventory (OTI). The latter scale assesses cognitive (6 items) and affective trust (6 items). Cognitive-based trust is defined as individual beliefs about dependability and competence and affective- 
based trust is described as having mutual interpersonal care and concern or emotional bonds with others (McAllister, 1995). The overall 12-item scale had a reliability of $\alpha=$ .93 , the 6-item affective component scale had a reliability of $\alpha=.82$ and the 6-item cognitive component had a reliability of $\alpha=.88$. For the Starting Out study (Laschinger et al., 2013) the stem wording, "I believe that my immediate supervisor/manager..." was used with five items from the Norman et al (2010) scale and rated using 5 points with the following anchors: $1=$ strongly disagree, $2=$ disagree, $3=$ hard to decide, $4=$ agree, $5=$ strongly agree. An example item for affective trust is: “...will keep his/her word” and an example item for cognitive trust is “...tells me the truth." Two additional items were added: “...is competent in his/her job" and "overall, I trust my immediate supervisor/manager." All items are averaged to achieve a scale score out of five. Cronbach's alpha for the seven-item scale was .96. Construct validity was assessed using exploratory factor analysis using principal component extraction which showed one factor with an eigenvalue value greater than 1.0 accounting for $82.05 \%$ of the variance (Wong, 2018). All seven items loaded on one factor and item loadings ranged from .77 to .88 suggesting a unidimensional scale.

\section{Data Collection}

The approach of Dillman et al., (2014) was used in the data collection procedure of the original study. The data were collected through mailed survey to a random sample of NGNs received from the ten provincial regulatory bodies lists of members during November 2012 to March 2013. The English version of the questionnaire was professionally translated into French and distributed to French-speaking participants. The survey package included a letter of information, study questionnaire, and pre-stamped return envelope was mailed to nurses' home addresses through Canada Post and also 
included a $\$ 2$ coffee voucher as a token of appreciation for participation. Also, nurses were provided with a ballot to indicate their interest of participation in a draw to win one of four iPads. To increase response rate, a reminder letter was sent four weeks after the initial package, and a second questionnaire package was sent to non-respondents 4 weeks after the reminder letter.

\section{Data Analysis}

The Statistical Package for Social Sciences (SPSS) version 25 (SPSS Inc. 2018) was used to analyze all data. Descriptive statistics (frequencies, means and standard deviations) for all scores on all scales were calculated. The normality of distribution was assessed using histograms, Q-Q plots, and skewness and kurtosis statistics. Missing data were assessed for amount and patterns using missing data analysis in SPPS. Cronbach's alpha reliability estimates were calculated for each instrument and subscales. The relationships among the main study variables, authentic leadership, manager incivility and trust in manager were assessed using Pearson correlations as well as the relationships between continuous demographic variables and main study variables. T-tests and analysis of variance (ANOVA) were performed to analyze for differences in major study variables by categorical demographic variables. Study hypotheses were tested using hierarchical multiple linear regression. The level of significance was set at $p<.05$ for all analyses. First, a simple bivariate regression was used to assess the relationship between authentic leadership and manager incivility. Second, with trust in manager as the dependent variable, authentic leadership was entered in the regression followed by manager incivility to test the hypothesized model.

\section{Results}

\section{Descriptive Results}

The means, standard deviations and reliability coefficients for the major study 
variables are found in Table 2. New graduate nurses in this study reported moderate authentic leadership of their manager $(M=2.60, S D=0.86)$. Of the ALQ subscales, internalized moral perspective was rated the highest $(M=2.75, S D=0.88)$, followed by relational transparency $(M=2.68, S D=0.89)$, and balanced processing $(M=2.56, S D=$ $0.95)$, and self-awareness was rated the lowest $(M=2.40, S D=1.06)$. Manager incivility was low $(M=0.74, S D=1.05)$ whereas the mean of trust in managers was moderate $(M=3.76, S D=0.96)$. All scale and subscale Cronbach alphas ranged from .83 to .96 and thus, were acceptable.

\section{Relationship of Demographic Variables to Major Study Variables}

There were no significant differences in the main study variables for the following demographic data: age, gender, educational level, and employment status. However, there was a significant difference in authentic leadership by specialty area $\left(F_{(7,997)}=2.501, p=\right.$ .015). New graduate nurses working in community health reported significantly higher authentic leadership $(M=2.99, S D=.97)$ than NGNs in medical surgical $(M=2.57, S D=.84)$ or critical care $(M=2.52, S D=.91)$ units. In addition, there were significant $(p<.05)$ negative, albeit weak, correlations between years of experience as a registered nurse $(r=$ -.09), in the organization $(r=-.10)$ and on the current unit $(r=-.09)$ with trust in the manager. Also, the number of years of experience as an RN was positively and significantly but weakly correlated with manager incivility $(r=.07, p<.05)$.

\section{Correlation Analysis}

The correlation matrix is presented in Table 2. Manager incivility was negatively correlated with authentic leadership $(r=-.46, p<.001)$ as well as the following subscales: relational transparency $(r=-.42, p<.001)$, internalized moral perspective $(r=-.41$, $p<.001)$, balanced processing $(r=-.40, p<.001)$, self-awareness $(r=-.44, p<.001)$. 
Manager incivility had a large negative correlation with trust in the manager $(r=-.56, p<$ .001. Authentic leadership was highly positively correlated with trust in the manager ( $r=$ $.73, p<.001)$. Trust was positively correlated with each subscale of authentic leadership where the strongest relationship was with relational transparency $(r=.70, p<.001)$ followed by self-awareness $(r=.67, p<.001)$, moral/ethical $(r=.66, p<.001)$ and balanced processing was the lowest $(r=.65, p<.001)$.

\section{Tests of Hypotheses}

First, a separate bivariate linear regression was performed to assess the relationship between authentic leadership and manager incivility (dependent variable) resulting in a significant negative relationship $((\beta=-.463, t=-16.565, p<.001)$. Then to test the relationship between authentic leadership and trust in the manager using hierarchical multiple linear regression, authentic leadership was entered first followed by manager incivility. Results showed that authentic leadership was significantly positively associated with trust in the manager $(\beta=.733, t=34.172, p<.001)$ and accounted for $53.8 \%$ $\left(F_{(1,1004)}=1167.746, p<.001\right)$ of the variance in trust in Model 1 (Table 3). When manager incivility was entered in Model 2, both authentic leadership $(\beta=.602, t=26.729$, $p<.001)$ and manager incivility $(\beta=-.282, t=-12.528, p<.001)$ were significant predictors of trust in the manager. Manager incivility accounted for an additional $6.3 \%\left(F_{(1,1003)}=\right.$ $156.961, p<.001)$ of the variance in trust. Together authentic leadership and manager incivility accounted for a total variance in trust of 59.9\%. Authentic leadership had a significant negative relationship with manager incivility and manager incivility was negatively associated with trust in the manager supporting the first hypothesis. Authentic leadership was directly and positively associated with trust in the manager supporting the second hypothesis. Findings of the final hypothesized model are displayed in Figure 2. 
Table 2

Means (M), Standard Deviations (SD), Reliabilities ( $\alpha$ ) and Correlation Matrix

\begin{tabular}{|c|c|c|c|c|c|c|c|c|c|}
\hline Variable & $\mathrm{M}$ & $\mathrm{SD}$ & $\alpha$ & 1 & 2 & 3 & 4 & 5 & 6 \\
\hline 1. Authentic Leadership & 2.60 & .87 & .96 & & & & & & \\
\hline 2. Self-Awareness- AL & 2.42 & 1.06 & .92 & $.93^{* * *}$ & & & & & \\
\hline 3. Balanced Processing-AL & 2.56 & .95 & .83 & $.92^{* * *}$ & $.83^{* * *}$ & & & & \\
\hline 4. Moral/Ethical Behaviour-AL & 2.75 & .89 & .87 & $.90^{* * *}$ & $.75^{* * *}$ & $.76^{* * *}$ & & & \\
\hline 5. Relational Transparency-AL & 2.69 & .89 & .88 & $.92^{* * *}$ & $.79^{* * *}$ & $.77^{* * *}$ & $.81^{* * *}$ & & \\
\hline 6. Leiter Supervisor Incivility & .74 & 1.05 & .90 & $-.46^{* * *}$ & $-.45^{* * *}$ & $-.41^{* * *}$ & $-.41^{* * *}$ & $-.43^{* * *}$ & \\
\hline 7. Trust in Management & 3.77 & .96 & .96 & $.74^{* * *}$ & $.68^{* * *}$ & $.65^{* * *}$ & $.67^{* * *}$ & $.70^{* * *}$ & $-.56^{* * *}$ \\
\hline
\end{tabular}

$* * * p<0.001$, two-tailed 
Table 3

Coefficients for Hypothesized Model $(N=1020)$

\begin{tabular}{llccccccc}
\hline \multirow{2}{*}{ Model } & Variables & $\mathrm{N}$ & $\mathrm{R}^{2}$ & $\begin{array}{c}\text { Adjusted } \\
\mathrm{R}^{2}\end{array}$ & $\beta$ & $\mathrm{t}$ & $\mathrm{p}$ \\
\hline \multirow{2}{*}{ Model 1 } & Authentic leadership & 1005 & .538 & .537 & .733 & 34.172 & $<.001$ \\
& & & & & & & \\
Model 2 & Authentic leadership & 1005 & .600 & .599 & .602 & 26.729 & $<.001$ \\
& Supervisor incivility & & & & -.282 & -12.528 & $<.001$ \\
& & & & & & & \\
\hline
\end{tabular}

Dependent Variable: Trust in Manager

All Betas reported are Standardized

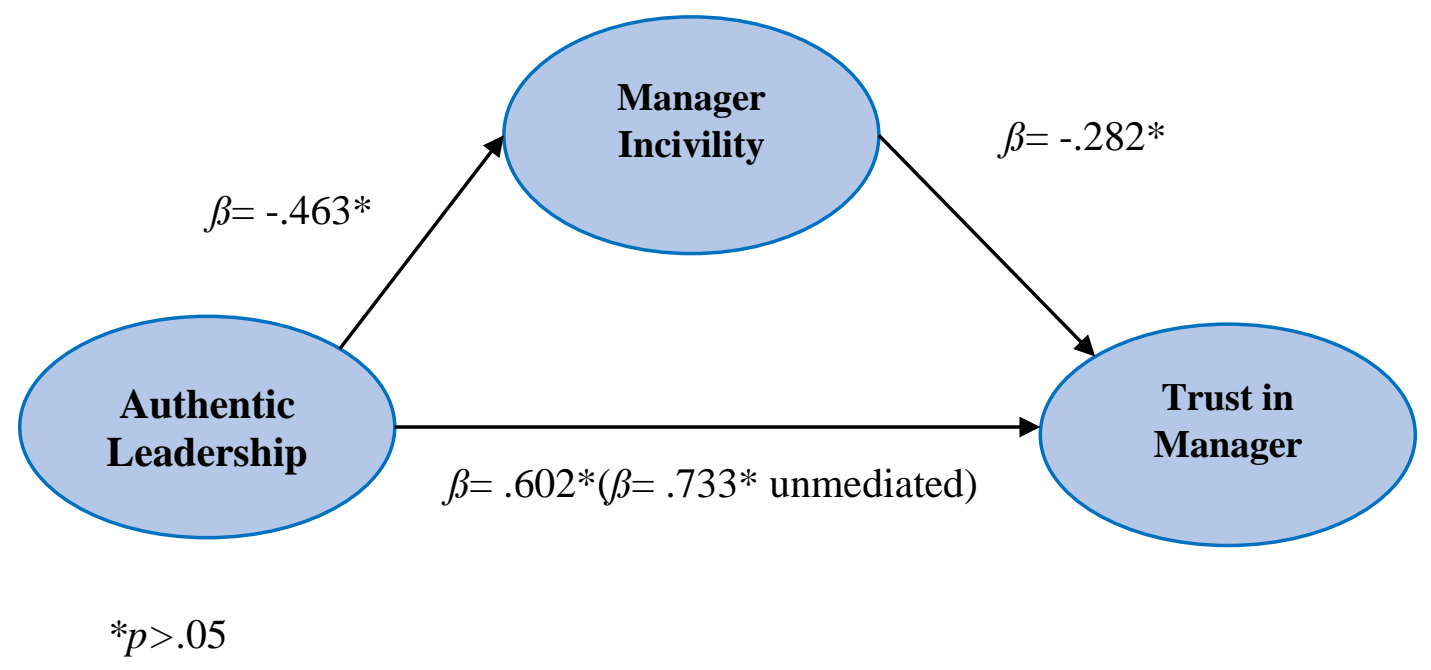

Figure.2. Final model 


\section{Discussion}

The purpose of this study was to test the relationship between authentic leadership of the manager, NGNs' experience of manager incivility and trust in their managers. The research was guided by authentic leadership theory (Avolio et al., 2004) which explains the influence of authentic leaders on their followers' attitudes, behaviour and performance. Both hypotheses for the study were supported. Authentic leadership was negatively associated with manager incivility which in turn was negatively associated with trust in managers. As far as is known, this is the first study that has tested the relationship between authentic leadership, manager incivility and trust in the manager in nursing. In addition, authentic leadership was directly and positively associated with trust in manager. Findings suggest that authentic leaders' behaviour may foster increased trust in their relationships with NGNs. Moreover, managers who engage in uncivil behaviours are more likely to decrease NGNs' trust in their manager, but authentic managers are less likely to be uncivil through their understanding of themselves, their ability to objectively evaluate their strengths and weaknesses, the consistency of their actions with their values and their openness and respect for others.

The findings highlight the significance of authentic leadership for manager-NGN relationships which is crucial for a healthy workplace environment. In this study, NGNs rated their managers to have a moderate level of authentic leadership $(M=2.60, S D=.87)$ and this is slightly higher than Read and Laschinger's (2013) recent study of NGNs $(M=2.47, S D=.86)$. This suggested that there may be some improvement in NGNs assessment of their managers' leadership style. With regard to the authentic leadership components, NGNs rated their managers as highest on internalized moral perspective $(M=2.75, S D=0.88)$, and lowest on self-awareness $(M=2.40, S D=1.06)$. Other NGN 
study findings have also shown that the moral perspective was the highest rated component of manager authentic leadership (Giallonardo et al., 2010; Fallatah \& Laschinger, 2016). Internalized moral perspective had a moderate negative association with manager incivility $(r=-.41, p<.01)$, showing that this component is inconsistent with displays of incivility. In addition, this component was also highly correlated with trust in the manager $(r=.66, p<.01)$ suggesting that managers who are guided by their morals and values rather than external influences, such an organizational pressures, are able to maintain civil behaviour toward NGNs which enhances trust development in the manager. Similarly, relational transparency was also moderately negatively associated with incivility $(r=-.42, p<.01)$ which may mean that striving for openness and honesty in one's communication is less likely to result in rude or disrespectful behavior. Even though the mean of self-awareness was the lowest rated component, this finding is consistent with other studies (Giallonardo et al., 2010; Laschinger \& Smith, 2013; Fallatah \& Laschinger, 2016). Self-awareness had the strongest negative correlation with manager incivility $(r=-.44, p<.01)$ among all ALQ subscales, and a high positive association with trust in managers $(r=.67, p<.01)$. These findings highlight the importance of managers seeking ongoing feedback from others and engaging in selfreflection as those with lower self-awareness may be enacting uncivil negative behaviours without understanding how those behaviours affect others (Walumbwa et al., 2008).

Authentic leadership was directly and positively associated with NGNs' trust in their manager and this is the first study showing this relationship among NGNs. This finding has been reported in a few studies examining the influence of authentic leadership on trust in managers among experienced nurses (Wong \& Cummings, 2009; Wong, 
Laschinger, and Cummings, 2010; Wong and Giallonardo, 2013). Additionally, in a sample of a variety of healthcare professionals that included nurses, authentic leadership was found to have a direct and positive relationhip with trust in the manager (Coxen et al.,2016). Similarly, outside of the nursing discipline, transparent managers were found to have a higher rate of follower trust (Hughes,2005; Norman, 2006, Norman, Avolio, Luthans, 2010). Relational transparency was the ALQ component most highly positively correlated with trust in the manager suggesting that this is one of the primary ways in which an authentic leader may facilitate trust. Relational transparency was defined by Avolio et al. (2004) as demonstrating openness and honesty when working with others. When managers share knowledge, provide constructive and respectful feedback about performance, encourage open and free communication with NGNs, and accept and appreciate their contributions to the workplace they develop trusting relationships with nurses. In a trusting work climate, nurses are more invested in their work and more likely to speak openly about their concerns and share suggestions for change (Wong, et al., 2010). Leaders who relate to their followers with openness and truthfulness are apt to be perceived as trusted leaders (Wong, et al., 2010). Although a significant association between authentic leadership and trust in the manager makes logical sense, less attention has been paid to understanding how authentic leaders influence trust (Wong et al., 2010). In fact, there have been few explicit studies conducted to understand trust in nursing leaders and its association with organizational outcomes (Hutchinson, 2018).

Finally, the negative association between authentic leadership and manager incivility may indicate that authentic leadership characteristics can minimize uncivil behaviors or attitudes. This finding is consistent with Read and Laschinger's (2013) study of NGNs. This suggests that authentic leaders may be more respectful to others which 
contributes to fostering a culture of respect in the workplace. The negative correlation between self- awareness and manager incivility can be explained through introspective self-reflection. When managers are aware of who they are, and constantly re-evaluate themselves and consider others' opinions before making decision, they will be less likely to engage in uncivil behavior. Open and honest conversation with nurses regarding their professional needs and expectations is one effective approach to enhance civility in healthcare organizations. Being genuine with others and supporting goals instead of personal interests generates fairness, which ultimately contributes to optimized collaboration among coworkers and minimized uncivil behaviors (Laschinger \& Read, 2016).

\section{Limitations}

Because this study was a secondary analysis of previously collected data, the researcher was limited to the measures and data collection methods of the original study. Since the study was cross-sectional and correlational, inferences of causality are limited to covariation among the variables and the theoretical foundation of the study (Taris, 2000). The use of a self-report survey may increase the likelihood of response bias (Polit $\&$ Beck, 2008). Also, even though the data were obtained from the 10 Canadian provinces, the sample population was NGNs with less than three years of experience which limits the generalizability of results to that population. Also the disproportionate random sampling method used may influence representativeness in that some provinces were over- or under-sampled given their respective populations of NGNs.

\section{Conclusion}

The study findings provide support for the relationship between authentic leadership behaviour on NGNs' perceptions of trust in their manager. The findings 
revealed that authentic leadership had a significant negative relationship with manager incivility which in turn was negatively associated with trust in the manager. The authentic leadership approach to management practice may reduce manager incivility and increase the amount of trust that NGNs develop in their managers. However, more focused attention on manager incivility and trust is needed to obtain sufficient understandings of the relationship between manager uncivil behavior and trust development in nursing management. 


\section{References}

Avolio, B.J. and Gardner, W.L. (2005), Authentic leadership development: getting to the root of positive forms of leadership. The Leadership Quarterly, 16 (3),315-38.

Avolio, B. J., Gardner, W. L., Walumbwa, F. O., Luthans, F., \& May, D. R. (2004). Unlocking the mask: A look at the process by which authentic leaders impact follower attitudes and behaviours. The Leadership Quarterly, 15, 801-823.

Avolio, B. J., Gardner, W. L., \& Walumbwa, F. O. (2007). Authentic leadership questionnaire. Available at: http://www.mindgarden.com, accessed August 15, 2018.

Avolio, B. J., Luthans, F., \& Walumbwa, F. O. (2004). Authentic leadership: Theory building for veritable sustained performance. Working paper. Gallup Leadership Institute, University of Nebraska-Lincoln.

Avolio, B.J. and Luthans, F. (2006), The high impact leader, McGraw-Hill, New York, NY.

Avolio, B., Walumbwa, F., \& Weber, T. (2009). Leadership: Current theories, research and future directions. Annual Review of Psychology, 60, 421-449

Appelbaum, S., Bartolomucci, N., Beaumier, E., Boulanger, J., Corrigan, R., Dore, I., ... \& Serroni, C. (2004). Organizational citizenship behavior: a case study of culture, leadership and trust. Management Decision, 42(1), 13-40.

Anderson, E., \& Weitz, B. (1989). Determinants of continuity in conventional industrial channel dyads. Marketing Science, 8, 310-323.

Andersson, L. M., \& Pearson, C. M. (1999). Tit for tat? The spiraling effect of incivility in the workplace. Academy of Management Review, 24(3), 452-471. 
Ashforth, B. E., \& Lee, R. T. (1990). Defensive behavior in organizations: A preliminary model. Human Relations, 43, 621-648.

Beddoes-Jones, F., \& Swailes, S. (2015). Authentic leadership: Development of a new three pillar model. Strategic Human Resources Review, 14(3), 94-99. h p://dx. doi.org/10.1108/SHR-04-2015-0032

Bowles, C., \& Candela, L. (2005). First job experiences of recent RN graduates: improving the work environment. Journal of Nursing Administration, 35(3), 130137.

Brower, H. H., Lester, S. W., Korsgaard, M. A., \& Dineen, B. R. (2009;2008;). A closer look at trust between managers and subordinates: Understanding the effects of both trusting and being trusted on subordinate outcomes. Journal of Management, 35(2), 327-347. 10.1177/0149206307312511

Canadian Nurses Association. Tested solutions for eliminating Canada's registered nurse shortage(2009).http://www.nurseone.ca/images/HHR/RN_shortage_Report_e.pdf Accessed July 9, 2018.

Canadian Nursing Advisory Committee. (2002). Our health, our future: Creating quality workplaces for Canadian nurses. Ottawa, ON: Author.

Chachula, K. M., Myrick, F., \& Yonge, O. (2015). Letting go: how newly graduated registered nurses in Western Canada decide to exit the nursing profession. Nurse education today, 35(7), 912-918.

Cho, J., Laschinger, H. S., \& Wong, C. (2006). Workplace empowerment, work engagement and organizational commitment of new graduate nurses. Nursing Leadership- Academy of Canadian Executive Nurses, 19(3), 43. 
Clapp-Smith, R., Vogelsang, G.R., \& Avey, J.B. (2009). Authentic leadership and positive psychological capital: The mediating role of trust at the group level of analysis. Journal of Leadership \& Organizational Studies, 15(3), 227-240. http://dx.doi.org/10.1177/1548051808326596

Clarke, C. M., \& Springer, P. J. (2012). Nurse residents' first-hand accounts on transition to practice. Nursing Outlook, 60(4), 2-8.

Coxen, L., van der Vaart, L., \& Stander, M. W. (2016). Authentic leadership and organisational citizenship behaviour in the public health care sector: The role of workplace trust. SA Journal of Industrial Psychology, 42(1), 13-pages.

Colquitt, J. A., Scott, B. A., \& LePine, J. A. (2007). Trust, trustworthiness, and trust propensity: A meta-analytic test of their unique relationships with risk taking and job performance. Journal of Applied Psychology, 92(4), 909-927. doi:10.1037/00219010.92.4.909.

Cummings, L. L., \& Bromiley, P. (1996). The organizational trust inventory (OTI). Trust in organizations: Frontiers of theory and research, 302(330), 39-52.

Darvish, H., \& Rezaei, F. (2011). The impact of authentic leadership on job satisfaction and team commitment. Management \& Marketing, 6(3), 421.

Deming, W. E. (1994). Foreword. In J. O. Whitney (Ed.), The trust factor: Liberating profits and restoring corporate vitality: New York: McGraw-Hill

Dillman, D. A., Smyth, J. D., \& Christian, L. M. (2014). Internet, phone, mail, and mixed-mode surveys: The tailored design method (Fourth ed.). Hoboken, New Jersey: Wiley. 
Dyess, S. M., \& Sherman, R. O. (2009). The first year of practice: New graduate nurses' transition and learning needs. The Journal of Continuing Education in Nursing, 40(9), 403-410.

Embree, J. L. \& White, A. H. (2010). Concept analysis: nurse-to-nurse lateral violence. NursingForum, 45(3), pp. 166-173

Estes, B., \& Wang, J. (2008). Integrative literature review: Workplace incivility: Impacts On individual and organizational performance. Human Resource Development Review, 7(2), 218240.

Fallatah, F., \& Laschinger, H. K. (2016). The influence of authentic leadership and supportive professional practice environments on new graduate nurses' job satisfaction. Journal of Research in Nursing, 21(2), 125-136.

Felblinger, D. M. (2008). Incivility and bullying in the workplace and nurses' shame responses. Journal of Obstetric, Gynecologic, \& Neonatal Nursing, 37(2), 234 242.

Ferres, N., \& Travaglione, T. (2003). Engendering trust in manager subordinate relationships: Predictors and outcomes. Personnel Review, 32(5), $569-587$.

Gaboury, I., M. Lapierre, L., Boon, H., \& Moher, D. (2011). Interprofessional collaboration within integrative healthcare clinics through the lens of the relationship-centered care model. Journal of Interprofessional Care, 25(2), 124130.

Gardner, W.L., Cogliser, C.C., Davis, K.A. \& Dickens M.P. (2011) Authentic leadership: a review of the literature and research agenda. The Leadership Quarterly 22(6), 1120-1145. 
Gardner, W.L., Avolio, B.J., Luthans, F., May, D.R. and Walumbwa, F. (2005), “Can you see the real me? A self-based model of authentic leaders and follower development", The Leadership Quarterly, 16(3), pp. 343-72.

Giallonardo, L. M., Wong, C. A., \& Iwasiw, C. L. (2010). Authentic leadership of preceptors:predictor of new graduate nurses' work engagement and job satisfaction. Journal of nursing management, 18(8), 993-1003

Harris, C. T. (2011). Incivility in nursing. Nursing Bulletin, 8(1), 16-20.

Hannah, S.T., Lester, P.B. and Vogelsang, G.R. (2005). Moral leadership: explicating the moral component of authentic leadership. In Gardner, W.L., Avolio, B.J. and Walumbwa, F.O. (Eds), Authentic leadership theory and practice: origins, effects and development (pp. 43-81). Oxford, UK: Elsevier.

Hershcovis, M.S. (2011). Incivility, social undermining, bullying ... oh my! A call To reconcile constructs within work- place aggressive research. Journal of Organizational Behavior, 32(3), 499- 519.

Hughes, L. W. (2005). Transparency, translucence or opacity? An experimental study of the impact of a leader's relational transparency and style of humor delivery on follower creative performance (unpublished doctoral dissertation). University of Nebraska. Retrieved from https://digitalcommons.unl.edu/dissertations/

\section{AAI3186859/.}

Hutchinson, M. (2018). The crisis of public trust in governance and institutions: Implications for nursing leadership. Journal of Nursing Management, 26(2), 83 85. 
James, L.J. (2011). The relationship between perceived organisational support and workplace trust: An exploratory study. (unpublished master's thesis). Western Cape, South Africa: University of the Western Cape. Retrieved August 2, 2015, from http://etd.uwc.ac.za/xmlui/bitstream/handle/11394/3188/ James_MCOM_2011.pdf? sequence=1.

Jawahar, I., \& Schreurs, B. (2018). Supervisor incivility and how it affects subordinates' performance: A matter of trust. Personnel Review, 47(3), 709-726. 10.1108/PR-01-2017-0022

Johnstone, M.J., Kanitsaki, O., Currie, T., 2008. The nature and implications of support incgraduate nurse transition programs: an Australian study. Journal of Professional Nursing. 24(1), 46-53. http://dx.doi.org/10.1016/ j.profnurs.2007.06.003

Kaiser, J. A. (2017). The relationship between leadership style and nurse-to-nurse incivility: turning the lens inward. Journal of Nursing Management, 25(2), 110118.

Kark, R., \& Shamir, B. (2002). The dual effect of transformational leadership: Priming relational and collective selves and further effects on followers. In B. J. Avolio, \& F.J. Yammarino (Eds.), Transformational and charismatic leadership: The road ahead (pp. 7-91). Oxford, UK: Elsevier.

Kelly, J., \& Ahern, K. (2009). Preparing nurses for practice: a phenomenological study of the new graduate in Australia. Journal of Clinical Nursing, 18(6), 910-918.

Kemppainen, V., Tossavainen, K., \& Turunen, H. (2013). Nurses' roles in health promotion practice: an integrative review. Health Promotion International, 28(4), 490-501. 
Kerber, C., Woith, W. M., Jenkins, S. H., \& Astroth, K. S. (2015). Perceptions of new nurses concerning incivility in the workplace. The Journal of Continuing Education in Nursing, 46(11), 522-527.

Kerfoot, K. (2006), Authentic leadership. Nursing Economics, 24 (2), pp. 116 17.

Kramer, M., \& Schmalenberg, C. (2008). Confirmation of a healthy work environment. Critical Care Nurse, 28(2), 56-63.

Laschinger, H. K. S., Cummings, G., Leiter, M., Wong, C., MacPhee, M., Ritchie, J., ... \& Young-Ritchie, C. (2016). Starting Out: A time-lagged study of new graduate nurses' transition to practice. International Journal of Nursing Studies, $57,82-95$.

Laschinger, H.K.S., Fida, R. (2014). A time-lagged analysis of the effect of authentic leadership on workplace bullying, burnout, and occupational turnover intentions. European Journal of Work and Organizational Psychology, 23(5), 739-753.

Laschinger, H. K. S., Finegan, J., Shamian, J., \& Casier, S. (2000). Organizational trust and empowerment in restructured healthcare settings: Effects on staff nurse commitment. JONA: The Journal of Nursing Administration, 30(9), 413-425. doi:10.1097/00005110-200009000-00008

Laschinger, H. K., Finegan, J., \& Shamian, J. (2001). The impact of workplace empowerment, organizational trust on staff nurses' work satisfaction and organizational commitment. Health Care Management Review, 26(3), 7-23.

Laschinger, H. K. S., \& Finegan, J. (2005). Using empowerment to build trust and respect in the workplace: A strategy for addressing the nursing shortage. Nursing economics, 23(1), 6 . 
Laschinger, H. K. S., Finegan, J., \& Wilk, P. (2009). New graduate burnout: the impact of professional practice environment, workplace civility, and empowerment. Nursing Economics, 27(6), 377.

Laschinger, H. K. S., Leiter, M. P., Day, A., Gilin-Oore, D., \& Mackinnon, S. P. (2012). Building empowering work environments that foster civility and organizational trust: Testing an intervention. Nursing Research, 61(5), 316-325.

Laschinger, H. K. S., \& Read, E. A. (2016). The effect of authentic leadership, person-job fit, and civility norms on new graduate nurses' experiences of coworker incivility and burnout. Journal of Nursing Administration, 46(11), 574-580.

Laschinger, H. K., \& Smith, L. M. (2013). The influence of authentic leadership and empowerment on new-graduate nurses' perceptions of interprofessional collaboration. Journal of Nursing Administration, 43(1), 24-29.

Laschinger, H. K. S., Wong, C. A., \& Grau, A. L. (2012). The influence of authentic leadership on newly graduated nurses' experiences of workplace bullying, burnout and retention outcomes: A cross-sectional study. International Journal of Nursing Studies, 49(10), 1266-1276

Laschinger, H. K., Wong, C., Regan, S., Young-Ritchie, C., \& Bushell, P. (2013). Workplace incivility and new graduate nurses' mental health: The protective role of resiliency. Journal of Nursing Administration, 43(7/8), 415-421.

Leiter, M. P., \& Day, A. (2013). Straightforward incivility scale manual. Technical Document: Centre for Organizational Research, Acadia University. 
Lewis, P. S., \& Malecha, A. (2011). The impact of workplace incivility on the work environment, manager skill, and productivity. Journal of Nursing Administration, $41,41-47$.

Luthans, F., \& Avolio, B. (2003). Authentic leadership: A positive development approach. In K.S. Cameron, J. E. Dutton, \& R. E. Quinn (Eds.), Positive organizational scholarship (pp.241-258). San Francisco, CA: Berrett-Koehler.

May, D.R., Chan, A., Hodges, T.D. and Avolio, B.J. (2003), "Developing the moral component of authentic leadership", Organizational Dynamics, 32(3), pp. 247-60.

Mayer, R. C., \& Gavin, M. B. (2005). Trust in management and performance: Who minds theshop while the employees watch the boss?. Academy of management journal, 48(5), 874-888.

Mayer, R. C., Davis, J. H., \& Schoorman, F. D. (1995). An integrative model of organizational trust. The Academy of Management Review, 20(3), 709-734. doi:10.1037/e574802013-344

Maslow, A. H. (1968). Motivation and personality. New York, NY: Harper \& Row. McAllister, D. J. (1995). Affect-and cognition-based trust as foundations for interpersonal cooperation in organizations. Academy of Management Journal, 38(1), 24-59.

McNamara, S.A. (2012) Incivility in nursing: unsafe nurse, unsafe patients. AORN Journal, 95(4), 535-540.

Men, L. R., \& Stacks, D. (2014). The effects of authentic leadership on strategic internal communication and employee-organization relationships. Journal of Public Relations Research, 26(4), 301-324. 
Millett, C. M., Stickler, L. M., \& Wang, H. (2015). Accelerated nursing degree programs: Insights into teaching and learning experiences. ETS Research Report Series, 2015(2), 1-32.

Morrow, S. (2009). New graduate transitions: leaving the nest, joining the flight. Journal of Nursing Management, 17(3), 278-287.

Neider, L.L., \& Schriesheim, C.A. (2011). The Authentic Leadership Inventory (ALI): Development and empirical tests. The Leadership Quarterly, 22(6), 1146-1164. H p://dx.doi.org/10.1016/j.leaqua.2011.09.008

Norman, S.M. (2006), The role of trust: implications for psychological capital and authentic leadership( unpublished doctoral dissertation). University of Nebraska, Lincoln, NE. Retrieved from https://digitalcommons.unl.edu/dissertations/ AAI3208085/

Norman, S. M., Avolio, B. J., \& Luthans, F. (2010). The impact of positivity and transparency on trust in leaders and their perceived effectiveness. The Leadership Quarterly, 21(3), 350-364.

Novicevic, M. M., Harvey, M. G., Buckley, M. R., Brown, J. A., \& Evans, R. (2006). Authentic leadership: A historical perspective. Journal of Leadership and Organizational Studies, 13, 6476.

Pearson, C. M., Andersson, L. M., \& Porath, C. L. (2000). Assessing and attacking workplace incivility. Organizational Dynamics, 29(2), 123-137.

Pearson, C. M., \& Porath, C. L. (2004). On incivility, its impact, and directions for future research. The dark side of organizational behavior, 16, 403-425. 
Peus, C., Wesche, J. S., Streicher, B., Braun, S., \& Frey, D. (2012). Authentic leadership: An empirical test of its antecedents, consequences, and mediating mechanisms. Journal of Business Ethics, 107(3), 331-348. doi: 10.1007/s10551-011-1042-3

Pierce, J., \& Gardner, D. 2004. Self-esteem within the work and organizational context: Areview of the organization-based self-esteem literature. Journal of Management, $30,591-622$.

Polit, D. F., \& Beck, C. T. (2017). Nursing research: Generating and assessing evidence for nursing practice. $\left(10^{\text {th }}\right.$ ed.). Netherlands: Wolters \& Kluwer.

Polit, D. F., \& Beck, C. T. (2008). Nursing research: Generating and assessing evidence for nursing practice. Lippincott Williams \& Wilkins.

Portoghese, I., Galletta, M., Leiter, M. P., \& Campagna, M. (2015). Factor structure of The straight forward incivility scale in an Italian sample. TPM-testing, psychometrics, methodology in applied psychology, 22(3), 315-325.

Rousseau, D. M., Sitkin, S. B., Burt, R. S., \& Camerer, C. (1998). Not so different after all: Across-discipline view of trust. Academy of Management Review, 23, 393404.

Read, E. A., \& Laschinger, H. K. (2015). The influence of authentic leadership and empowerment on nurses' relational social capital, mental health and job satisfaction over the first year of practice. Journal of Advanced Nursing, 71(7), $1611-1623$.

Read, E., \& Laschinger, H. K. (2013). Correlates of new graduate nurses' experiences of workplace mistreatment. Journal of Nursing Administration, 43(4), 221-228. 
Regan, S., Wong, C., Laschinger, H. K., Cummings, G., Leiter, M., MacPhee, M., . . Read, E. (2017). Starting out: Qualitative perspectives of new graduate nurses and nurse leaders on transition to practice. Journal of Nursing Management, 25(4), 246-255. 10.1111/jonm.12456

Registered Nurses' Association of Ontario (RNAO) (2013). Developing and Sustaining Nursing Leadership second edition, RNAO, Toronto. Retrieved from: http://rnao.ca/sites/rnao-ca/files/LeadershipBPG_Booklet_Web_1.pdf.

Robinson, S.L. \& Bennett, R.J. (1995) A typology of deviant workplace behaviors: a multidimensional scaling study. Academy of Management Journal, 38, 555-572.

Rogers, C. (1961). On becoming a person: A therapist's view of psychotherapy. Boston, MA: Houghton Mifflin.

Rush, K. L., Adamack, M., Gordon, J., \& Janke, R. (2014). New graduate nurse transition programs: Relationships with bullying and access to support. Contemporary nurse, 48(2), 219-228.

Rush, K. L., Adamack, M., Gordon, J., Lilly, M., \& Janke, R. (2013). Best practices of formal new graduate nurse transition programs: an integrative review. International journal of nursing studies, 50(3), 345-356.

Scott, E. S., Engelke, M. K., \& Swanson, M. (2008). New graduate nurse transitioning: necessary or nice?. Applied Nursing Research, 21(2), 75-83

Shirey, M.R. (2006), Authentic leaders creating healthy work environments for nursing practice, American Journal of Critical Care, 15(3), 256-67.

Staples, D.S. (2001), "A study of remote workers and their differences from non-remote workers", Journal of End User Computing,13(2), 3. 
Sypher, B. D., \& Gill, M. (2009). Incivility and organizational trust. In P. Lutgen Sandvik \& B.D. Sypher (Eds.), Destructive organizational communication. New York, NY: Routledge.

Tajfel, H. (1974). Social identity and intergroup behaviour. Information (International Social Science Council), 13(2), 65-93.

Taris, T. (2000). A primer in longitudinal data analysis. Thousand Oaks, CA: Sage Publications, Ltd.

Walsh, B. M., Magley, V. J., Reeves, D. W., Davies-Schrils, K. A., Marmet, M. D., \& Gallus, J. A. (2012). Assessing workgroup norms for civility: The development of the Civility Norms Questionnaire-Brief. Journal of Business and Psychology, 27(4), 407-420

Walumbwa, F.O., Avolio, B.J., \& Gardner, W.L. (2008). Authentic leadership: development and validation of a theory-based measure, Journal of Management 34(1), 89-126.

Walumbwa, F. O., Avolio, B. J., Gardner, W. L., Wernsing, T. S., \& Peterson, S. J. (2008;2007;). Authentic leadership: Development and validation of a theorybased measure. Journal of Management, 34(1), 89-126. doi:10.1177/0149206307308913

Whitener, E. M., Brodt, S. E., Korsgaard, M. A., \& Werner, J. M. (1998). Managers as initiators of trust: An exchange relationship framework for understanding managerial trustworthy behavior. Academy of Management Review, 23, 513-530.

Wong, C.A. (2018). Exploratory factor analysis of trust in manager scale. Unpublished research report, Western University. 
Wong, C., \& Cummings, G. (2009). Authentic leadership: a new theory for nursing or back to basics? Journal of Health Organization and Management, 23(5), 522-538.

Wong, C. A., \& M Giallonardo, L. (2013). Authentic leadership and nurse-assessed Adverse patient outcomes. Journal of Nursing Management, 21(5), 740-752.

Wong, C. A., Laschinger, H. K. S., \& Cummings, G. G. (2010). Authentic leadership and nurses' voice behaviour and perceptions of care quality. Journal of Nursing Management, 18(8), 889-900 


\section{CHAPTER 3}

\section{DISCUSSION}

The purpose of this study was to examine the relationship among authentic leadership of managers, NGNs' experience of manager incivility and trust in managers in a sample of NGNs in 10 Canadian provinces. The study was guided by Avolio et al.'s (2004) theory of authentic leadership. The results showed that authentic leadership was negatively related to manager incivility which in turn was negatively associated with trust in the manager. Also, authentic leadership was found to have a direct positive relationship with trust in the manager. These findings highlight the significance of authentic leadership in minimizing incivility and fostering trusting relationships. Leaders who have high self-awareness are able to maintain civil behaviors toward NGNs. Additionally, being transparent in one's demeanor and communication contribute to an increased degree of trust that NGNs have in their managers. The implication of this study's findings for theory, healthcare organizations, and nursing management are discussed in the following sections of this chapter.

\section{Implications for Theory}

The findings of this study supported authentic leadership theory which proposes that the authentic leader has a positive influence on their followers' attitudes, behaviour and performance (Avolio, Gardner, Walumbwa, Luthans \& May, 2004). Authentic leadership had a negative relationship with manager's incivility which in turn was negatively associated with trust in the manager indicating that when a leader exhibits uncivil behavior toward NGNs, they may diminish NGNs' trust in them. This finding aligns with Avolio et al.'s (2004) authentic leadership theory in that when authentic leaders' actions are consistent with their core values and beliefs, they are perceived as 
having integrity and are trusted by followers. As far as it is known, this is the first study that tested the relationship between authentic leadership, manager incivility, and trust in the managers in the nursing discipline. Although other mediators in the theory such as, personal and social identification, were not assessed in this study, the results add to a small body of research support for the link between authentic leadership and trust in nursing.

\section{Implications for Healthcare Organizations}

Uncivil behaviours can be costly to health organizations. Job stress due to incivility in United State corporations cost $\$ 300$ billion a year (Leiter \& Maslach, 2005). Workplace incivility hinders nurses' productivity, creativity and their commitment to the organization (Harris, 2011). Moreover, leaders and managers have the responsibility to create positive and effective organizational cultures (Laschinger, Finegan, \& Wilk, 2009; Shirey 2006). Authentic leadership has been positively related to fostering positive relationships in the workplace (Giallonardo, Wong \& Iwasiw, 2010). Similarly, Avolio and Gardner (2005), highlighted that maintaining integrity and being able to engage in balanced processing contributes to respectful and trustworthy leader-subordinate relationships which ultimately lead to a healthy workplace environment.

This study's findings provide evidence that authentic leadership may positively facilitate a healthy workplace environment through reducing incivility and enhancing trust in the manager. The finding suggests that organizations need to create an organizational culture that is based on the authentic leadership approach. Authentic leadership development programs and training may be beneficial to provide managers with tools to become more authentic and effective in communicating and relating with nurses (Fallatah, Laschinger, \& Read, 2017). These programs may instruct managers in 
how to be self-aware, to reflect on their values, and direct them in how to be more transparent (Leroy, Anseel, Gardener, \& Sels, 2012). Nursing managers should receive development training in essential skills such as how to effectively communicate, provide constructive feedback, and integrate different points of view of staff in their decisionmaking processes.

Furthermore, this study provides evidence linking authentic leadership with increased trust in a manager and less incivility from the manager. When nursing managers are guided by authentic leadership principles in the workplace, decreased incidence of incivility and stronger trusting relationships may be achieved. Clear policies supporting civility in the workplace should be implemented. This policy should have an emphasis on open and respectful communication. It also should explain what acceptable behaviors look like and how NGNs can contribute to unit decision making processes. In addition, organization leaders need to ensure that NGNs have been supervised by those who demonstrate all four components of authentic leadership. The implementation of authentic leadership based policies can maintain the positive impacts of authentic leadership approach on NGNs.

\section{Implication for Healthcare Management Practice}

Study findings suggest that authentic leadership can make a vital contribution to minimizing manager incivility. Authentic leaders are less likely to exhibit disrespectful behaviors and more likely to be open with their followers, acknowledge their values and beliefs, and consider others' opinions before making any decision resulting in fostering trusting relationship with manager; thus, NGNs will feel secure in dealing and communicating with their managers. Authentic leadership has been identified as one of six standards that help establish and sustain healthy organizational culture (The American 
Association of Critical-Care Nurses, 2005). Therefore, authentic leadership knowledge could benefit managers in facilitating NGNs transition to nursing practice and sustain a healthy workplace culture.

The authentic leadership approach emphasizes raising one's self-awareness about relationships with others. When nurses become fully aware of what negatively affects them, they can respond to it appropriately. Authentic leaders can provide educational sessions for NGNs on what incivility involves, and teach them behavioral techniques to help them be strong, independent, and stand up for themselves. Coaching sessions and constructive feedback are examples of authentic leadership that assist in motivating nurses and instilling self-determination, which in turn promotes follower autonomy (Gardner et al., 2005; Ilies et al., 2005). For example, McNamara (2012) proposed that teaching nurses to use pre-rehearsed responses, such as "I don't think that is appropriate" in response to negative behavior could successfully work in reducing workplace incivility.

Moreover, Avolio et al. (2004) emphasized the importance of establishing trustworthy relationships between leaders and their followers by encouraging free communication, fairness, and sharing information and feelings. Authenticity of leaders can be displayed by maintaining effective communication with NGNs. Authentic leaders reinforce a high level of openness with others and share information that helps facilitate two-way communication. Open and honest conversation with nurses regarding their professional needs and expectations is one effective approach to enhance civility norms in healthcare organizations (Laschinger \& Read, 2016). An effective communication training program can profoundly reduce workplace incivility (McNamara, 2010). Nursing managers need to be perceived as approachable by NGNs, allow them to share their 
opinions and feelings and consider them in making decisions to ensure their voices are heard by higher levels of authority in the organization.

\section{Implication for Future Research}

Because NGNs are valuable resources in the profession (Read \& Laschinger, 2013) continued attention to this population must be made in future research. The influence of authentic leaders' behaviour on NGNs perceptions and their relationships with immediate supervisors requires more investigation as well as the consequences of manager uncivil behaviours on NGNs psychological and professional wellbeing. Both quantitative and qualitative research studies are needed to provide a greater understanding of NGNs transition into nursing practice. Furthermore, only a few studies have examined the relationship between authentic leadership and trust (Wong \& Cummings, 2009; Wong, Laschinger, and Cummings, 2010; Wong and Giallonardo, 2013), and one other study has tested the relationship between authentic leadership and incivility (Read \& Laschinger, 2013). The association between authentic leadership and trust is rarely examined in the nursing discipline (Wong, et al., 2010). Using a qualitative approach to explore how NGNs perceive trust in their manager would provide insights into how trust is developed. Quantitative studies of NGNs using other trust scales such as Mayer and Gavin's (2005) Trust in Management Scale would provide (Mayer \& Gavin 2005) more comprehensive data on trust that could be compared to other studies of trust among experienced nurses (Wong et al. 2010). The relationship between authentic leadership and trust with organizational outcomes such as quality of care, nurse performance, or job turnover intentions are important research opportunities to be pursued. 
The mediation effect of incivility between authentic leadership and trust in the manager can be explored in other studies as well as the mediating relationships between authentic leadership and trust through personal and social identification. Future research should investigate how personal identification with the leader can influence trust development, and how the degree of identification with the work group affects leadernurse relationships. Also, researchers could examine the mediation effect of trust between authentic leadership and other organizational outcomes. Although the results of this study support the hypothesized model and add important knowledge to nursing literature, future research in this regard is warranted.

\section{Conclusion}

In summary, study findings support the theoretical propositions of authentic leadership developed by Avolio et al. (2004) and demonstrate the importance of authentic leadership on NGNs relationships with their managers. Authentic leadership had a negative relationship with manager incivility which in turn was negatively related to trust in the manager; as well there was a direct positive association with trust in the manager. These relationships were explained through the four components of authentic leadership, self-awareness, relational transparency, internalized moral perspective and balanced processing. There are meaningful implications for theory, management practice, and future research based on this study. Authentic leadership may be useful to guide the development of authentic leadership in healthcare organizations, inform the education and training of managers, and teach NGNs about important leader behaviours. More rigorous research is needed in this area in order to promote a better understanding of the relationships among these variables and to evaluate and provide support for authentic leadership educational programs. 


\section{References}

American Association of Critical-Care Nurses. (2005). AACN standards for establishing and sustaining healthy work environments: a journey to excellence. American Journal of Critical Care, 14(3), 187-197.

Avolio, B.J. and Gardner, W.L. (2005), Authentic leadership development: getting to the root of positive forms of leadership. The Leadership Quarterly, 16 (3),315-38

Avolio, B. J., Gardner, W. L., Walumbwa, F. O., Luthans, F., \& May, D. R. (2004). Unlockingthe mask: A look at the process by which authentic leaders impact follower attitudes and behaviours. The Leadership Quarterly, 15, 801-823.

Ilies, R., Morgeson, F. P., \& Nahrgang, J. D. (2005). Authentic leadership and eudaemonic well-being: Understanding leader-follower outcomes. The Leadership Quarterly, 16(3), 373-394.

Fallatah, F., Laschinger, H. K., \& Read, E. A. (2017). The effects of authentic leadership, organizational identification, and occupational coping self-efficacy on new graduate nurses' job turnover intentions in Canada. Nursing Outlook, 65(2), 172183.

Gardner, W.L., Avolio, B.J., Luthans, F., May, D.R. and Walumbwa, F. (2005), Can you see the real me? A self-based model of authentic leaders and follower development? The Leadership Quarterly, 16(3), 343-72.

Giallonardo, L. M., Wong, C. A., \& Iwasiw, C. L. (2010). Authentic leadership of preceptors: predictor of new graduate nurses' work engagement and job satisfaction. Journal of Nursing Management, 18(8), 993-1003.

Harris, C. T. (2011). Incivility in nursing. Nursing Bulletin, 8(1), 16-20. 
Laschinger, H. K. S., Finegan, J., \& Wilk, P. (2009). Context matters: The impact of unit leadership and empowerment on nurses' organizational commitment. Journal of Nursing Administration, 39(5), 228-235.

Laschinger, H. K. S., \& Read, E. A. (2016). The effect of authentic leadership, person-job fit, and civility norms on new graduate nurses' experiences of coworker incivility and burnout. Journal of Nursing Administration, 46(11), 574-580.

Leiter, M. P., \& Maslach, C. (2005). Banishing burnout: Six strategies for improving your relationship with work. John Wiley \& Sons.

Leroy, H., Anseel, F., Gardner, W. L., \& Sels, L. (2015). Authentic leadership, authentic followership, basic need satisfaction, and work role performance: A cross-level study. Journal of Management, 41(6), 1677-1697.

Mayer, R. C., \& Gavin, M. B. (2005). Trust in management and performance: Who minds the shop while the employees watch the boss?. Academy of management journal, 48(5), 874-888.

McNamara, S. A. (2012). Incivility in nursing: Unsafe nurse, unsafe patients. AORN journal, 95(4), 535-540.

Read, E., \& Laschinger, H. K. (2013). Correlates of new graduate nurses' experiences of workplace mistreatment. Journal of Nursing Administration, 43(4), 221-228.

Shirey, M. R. (2006). Authentic leaders creating healthy work environments for nursing practice. American Journal of Critical Care, 15(3), 256-267.

Wong, C., \& Cummings, G. (2009). Authentic leadership: a new theory for nursing or back to basics? Journal of Health Organization and Management, $23(5), 522-538$. 
Wong, C. A., \& M. Giallonardo, L. (2013). Authentic leadership and nurse-assessed adverse patient outcomes. Journal of Nursing Management, 21(5), 740-752.

Wong, C. A., Laschinger, H. K. S., \& Cummings, G. G. (2010). Authentic leadership and nurses' voice behaviour and perceptions of care quality. Journal of Nursing Management, 18(8), 889-900. 


\section{Appendix A}

\section{Ethical Approval Form for Original Study}

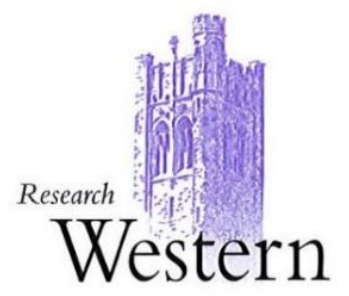

Use of Human Participants - Ethics Approval Notice

Principal Investigator: Dr. Heather Laschinger

File Number: 102638

Review Level:Delegated

Approved Local Adult Participants: 4940

Approved Local Minor Participants:0

Protocol Title:STARTING Out: Successful Transition and Retention in New Graduate Nurses

Department \& Institution:Health SciencesWursing,Western University

Sponsor:Canadian Institutes of Health Research

Ethics Approval Date:June 12, 2012 Expiry Date:March 31, 2016

Documents Reviewed \& Approved \& Documents Received for Information:

Document Name

Comments

Version

Date

Western University

Protocol

Advertisement

Letter of Information

Letter of Information \&

Consent

Letter of Information \&

Consent

APPENDIX C: Focus Group Recruitment Posters

Survey Letter of Information - New Graduates

Focus Group Letter of Information and Consent -

New Graduates

Focus Group Letter of Information and Consent -

Experience Nurses

Letter of Information

Survey Letter of Information - Experienced Nurses

This is to notify you that The University of Western Ontario Research Ethics Board for Health Sciences Research Involving Human Subjects (HSREB) which is organized and operates according to the Tri-Council Policy Statement: Ethical Conduct of Research Involving Humans and the Health Canada/lCH Good Clinical Practice Practices: Consolidated Guidelines; and the applicable laws and regulations of Ontario has reviewed and granted approval to the above referenced revision(s) or amendment(s) on the approval date noted above. The membership of this REB also complies with the membership requirements for REB's as defined in Division 5 of the Food and Drug Regulations.

The ethics approval for this study shall remain valid until the expiry date noted above assuming timely and acceptable responses to the HSREB's periodic requests for surveillance and monitoring information. If you require an updated approval notice prior to that time you must request it using the University of Western Ontario Updated Approval Request Form.

Members of the HSREB who are named as investigators in research studies, or declare a conflict of interest, do not participate in discussion related to, nor vote on, such studies when they are presented to the HSREB.

The Chair of the HSREB is Dr. Joseph Gilbert. The HSREB is registered with the U.S. Department of Health \& Human Services under the IRB registration number IRB 00000940

Sign

\begin{tabular}{|c|c|c|}
\hline $\begin{array}{l}\text { Janice Sutherland } \\
\text { (Esther }\end{array}$ & Grace Kelly & $\begin{array}{l}\text { Shantel Walcott } \\
\text { (swalcotauwo }\end{array}$ \\
\hline
\end{tabular}

This is an official document. Please retain the original in your files.

The University of Western Ontario

Office of Research Ethics

Support Services Building Room 5150 • London, Ontario • CANADA - N6G 1G9

PH: 519-661-3036•F: 519-850-2466• ethics@uwo.ca • www.uwo.ca/research/ethics 


\section{Appendix B}

\section{Study Instruments}
B. 01 Authentic Leadership Questionnaire
B. 02 Permission to Use ALQ
B. 03 Straightforward Incivility Scale - Supervisor Incivility
B. 04 Trust in Manager
B. 05 Demographic Questionnaire 
Authentic Leadership Questionnaire

(Avolio, Gardner, \& Walumbwa, 2007)

Please rate how OFTEN your leader (immediate supervisor):

\begin{tabular}{|l|r|r|r|r|r|}
\hline & $\begin{array}{l}\text { Not at } \\
\text { all }\end{array}$ & $\begin{array}{l}\text { One in } \\
\text { awhile }\end{array}$ & $\begin{array}{l}\text { Some- } \\
\text { times }\end{array}$ & $\begin{array}{l}\text { Fairly } \\
\text { Often }\end{array}$ & $\begin{array}{l}\text { Frequently, } \\
\text { if not } \\
\text { always }\end{array}$ \\
\hline 1. Says exactly what he or she means. & 0 & 1 & 2 & 3 & 4 \\
\hline $\begin{array}{l}\text { 2. Demonstrates beliefs that are } \\
\text { consistent with actions. }\end{array}$ & 0 & 1 & 2 & 3 & 4 \\
\hline $\begin{array}{l}\text { 3. Solicits views that challenge his or } \\
\text { her deeply held positions. }\end{array}$ & 0 & 1 & 2 & 3 & 4 \\
\hline $\begin{array}{l}\text { 4. Seeks feedback to improve } \\
\text { interactions with others. }\end{array}$ & 0 & 1 & 2 & 3 & 4 \\
\hline
\end{tabular}

Due to copyright restrictions, only four items are included in this appendix.

\begin{tabular}{|c|}
\hline Legend \\
Self-Awareness: 4 \\
Relational Transparency: 1 \\
Internalized Moral Perspective: 2 \\
Balanced Processing: 3 \\
\hline
\end{tabular}




\section{Permission to use ALQ}

\section{m户nd garden www.mindgarden.com}

To whom it may concern,

This letter is to grant permission for the above named person to use the following copyright material;

Instrument: Authentic Leadership Questionnaire (ALQ)

Authors: Bruce J. Avolio, William L. Gardner, and Fred O. Walumbwa

Copyright: "Copyright $\odot 2007$ Authentic Leadership Questionnaire (ALQ) by Bruce J. Avolio, William L. Gardner, and Fred O. Walumbwa. All rights reserved in all medium."

for his/her thesis research.

Five sample items from this instrument may be reproduced for inclusion in a proposal, thesis, or dissertation.

ot be included or reproduced at any time in any other published

Sincerely,

Robert Most

Mind Garden, Inc.

www.mindgarden.com 


\section{Straightforward Incivility Scale - Supervisor Incivility}

(Leiter \& Day, 2013)

Over the past month, how OFTEN have ...

\begin{tabular}{|l|l|l|l|l|l|l|}
\hline $0=$ Never & $1=$ Sporadically & $2=$ Now And Then & $3=$ Regularly & $4=$ Often & $5=$ Very Often & $6=$ Daily \\
\hline
\end{tabular}

\section{... your supervisors behaved in the following ways?}

1. Ignored you.

2. Excluded you.

3. Spoke rudely to you.

4. Behaved rudely to you.

5. Behaved without consideration for you.

$\begin{array}{lllllll}0 & 1 & 2 & 3 & 4 & 5 & 6\end{array}$

$\begin{array}{lllllll}0 & 1 & 2 & 3 & 4 & 5 & 6\end{array}$

$\begin{array}{lllllll}0 & 1 & 2 & 3 & 4 & 5 & 6\end{array}$

$\begin{array}{lllllll}0 & 1 & 2 & 3 & 4 & 5 & 6\end{array}$

$\begin{array}{lllllll}0 & 1 & 2 & 3 & 4 & 5 & 6\end{array}$




\section{Trust in Manager}

(Laschinger et al, 2012; Norman et al., 2010)

\section{Please rate the EXTENT to which you AGREE with the following:}

$$
1=\text { Strongly Disagree } \quad 2=\text { Disagree } \quad 3=\text { Hard to Decide } \quad 4=\text { Agree } 5=\text { Strongly Agree }
$$

\section{I believe that my immediate supervisor/manager...}

1. Will keep his/her word.

2. Is reliable.

3. Deals with me honestly.

4. Establishes and communicates expectations fairly.

5. Tells me the truth.

6. Is competent in his/her job.

7. Overall, I trust my immediate supervisor/manager. $\begin{array}{lllll}1 & 2 & 3 & 4 & 5\end{array}$

$\begin{array}{lllll}1 & 2 & 3 & 4 & 5\end{array}$

$\begin{array}{lllll}1 & 2 & 3 & 4 & 5\end{array}$

$\begin{array}{lllll}1 & 2 & 3 & 4 & 5\end{array}$

$\begin{array}{lllll}1 & 2 & 3 & 4 & 5\end{array}$

$\begin{array}{lllll}1 & 2 & 3 & 4 & 5\end{array}$

$\begin{array}{lllll}1 & 2 & 3 & 4 & 5\end{array}$




\section{Demographic Questionnaire}

1. Age (In years)

2. Gender: $\square$ Female $\square$ Male

3. Date of Graduation (Month, Year)

4. HIGHEST DEGREE received in Nursing:

$\square$ Bachelors Degree of Nursing $\quad \square$ Master's Degree in Nursing

$\square$ College Nursing Diploma $\quad \square$ Other:

5. Current Employment Status: $\square$ Full-Time $\quad \square$ Part-Time $\square$ Casual

6. Average hours worked per week______(hours)

7. Average overtime hours worked per week_____ (hours)

8. How long have you worked:

As an RN:

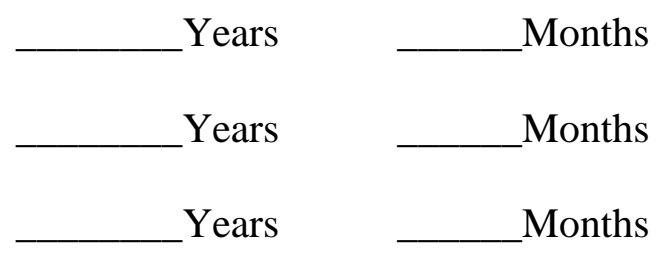

As an $\mathrm{RN}$ on your current unit

9. Specialty area of your current place of work / unit:

$\square$ Medical-Surgical $\square$ Critical Care $\quad \square$ Maternal-Child $\square$ Mental Health

$\square$ Float Pool or Nursing Resource Unit $\square$ Community Health

$\square$ Long Term Care $\quad \square$ Other, please specify: 


\section{Appendix C}

\section{Letter of Information}

\section{Western}

Arthur Labatt Family

School of Nursing

Project Title: STARTING Out: Successful Transition and Retention in New Graduate Nurses

\section{Principal Investigator:}

Heather K. Laschinger, RN, PhD, FAAN, FCAHS - The University of Western Ontario

\section{SURVEY LETTER OF INFORMATION FOR NEW GRADUATE NURSES}

\section{Invitation to Participate}

You are being invited to participate in this research study examining new graduate nurses' transition to practice because you are newly graduated practicing registered nurse and we would like to hear your feedback about your transition experience.

\section{Purpose of the Letter}

The purpose of this letter is to provide you with information required for you to make an informed decision regarding participation in this research.

\section{Purpose of the Study}

The purpose of this study is to describe new graduate nurses' worklife experiences in Canadian health care settings in the first two years of practice and to examine predictors of job and career satisfaction and turnover intentions across this timeframe. Additionally we would like to gain an increased understanding of the current nursing work environment through the lens of experienced nurses across the country.

\section{Inclusion Criteria}

In order to participate in this research project you must be a practicing registered nurse who has graduated sometime after January $01^{\text {st }}, 2011$.

\section{Study Procedures}

If you agree to participate, you will be asked to complete the included survey consisting of questions examining the influence of the current nursing work environment on your transition to the full professional role. It is anticipated that the entire task will take approximately 20 minutes of your time. This survey has been sent to 400 newly graduated nurses in each province across Canada, and 1600 experienced nurses across the country. Once you have completed your survey, please place it in the self-addressed 
envelope provided and put it in the mail. You may keep the enclosed \$2 Tim Hortons card whether or not you choose to complete the survey. If you choose to participate you will receive a follow-up survey one year later to track your transition experience across time.

\section{Possible Risks and Harms}

There are no known or anticipated risks associated with participating in this study. There is a chance that you may feel uncomfortable answering questions about your work environment on the survey. Care will be taken to ensure confidentiality of survey data and we will respect your privacy. Also, you will not have to answer any questions if you feel uncomfortable. You may refer to your Employee Assistance Plan representative if you need to talk to someone further about these issues.

\section{Possible Benefits}

We cannot guarantee you any direct benefits as a result of your participation in this study. However, this study will indicate personal and situational factors that influence new graduate and nurses' satisfaction and intentions to remain in their jobs and the profession within the first two years of practice. This information can be used to retain a satisfied and engaged workforce.

In addition, further knowledge of the value and benefits of formal nursing graduate transition support programs across Canada will be discussed. As a result, this information can be used to inform policy and organizational initiatives that will attract and retain new graduate nurses. Lastly, the feedback from experienced nurses across the country regarding current nursing work environments will enable us to frame the results within different cohorts of nurses.

\section{Compensation}

You have received a $\$ 2$ Tim Hortons card as a token of appreciation for your time to complete the questionnaire. You may keep the enclosed \$2 Tim Hortons card whether or not you choose to complete the survey.

\section{Voluntary Participation}

Participation in this study is voluntary. You may refuse to participate, refuse to answer any questions or withdraw from the study at any time with no effect on your future employment.

\section{Confidentiality and Privacy}

As a participant you will be given a personal identification number (PIN) in order to link your data across timeframes for the survey. The Researchers at The University of Western Ontario will link study PINs to your name only for the purposes of distributing information letters and surveys to you. Data will be sent directly to Western with only the PIN as the identifier. All participant names and assigned PINs will be destroyed as soon as the data collection is complete. The survey distribution will consist of the survey included here, a reminder letter four weeks later to non-respondents, and finally a second distribution of the survey asking non-respondents to complete the survey if they haven't yet done so. 
All data collected will remain confidential and accessible only to the investigators of this study. If the results are published, your name will not be used. If you choose to withdraw from this study, your data will be removed and destroyed from our database.

Representatives of The University of Western Ontario Health Sciences Research Ethics Board may contact you or require access to your study-related records to monitor the conduct of the research.

\section{Consent}

Completion of the survey is indication of your consent to participate.

Sincerely,

Heather K. Spence Laschinger, RN, PhD, FAAN, FCAHS

Distinguished University Professor

Nursing Research Chair in Health Human Resource Optimization

Arthur Labatt Family School of Nursing

The University of Western Ontario

This letter is yours to keep for future reference. 


\section{Curriculum Vitae}

Name

Post-Secondary Education and Degrees

Honours and Awards

Related Work Experience:

Professional Memberships
Ohood Alkaabi

The University of Western Ontario

London, ON, Canada

2016-2018 MScN

Umm Al-Quraa University

Makkah, Saudi Arabia

2008-2011, B.A. General Nursing

Saudi scholarship 2014- 2019

Teaching Assistant and Clinical Instructor

Faculty of Nursing, King Khalid University

Abha, Saudi Arabia

Registered Nurse at Saudi Commission for Health Specialists

Makkah, Saudi Arabia 